\title{
6-Öğretmen adaylarının akademik yazma eğitimine yönelik görüşleri
}

\section{Ayşegül ERGİşí1}

\section{Çiğdem KOZANER YENIGÜL²}

\begin{abstract}
APA: Ergişi, A.; Kozener Yenigül, Ç. (2020). Öğretmen adaylarının akademik yazma eğitimine yönelik görüşleri. RumeliDE Dil ve Edebiyat Araştırmaları Dergisi, (21), 100-125. DOI: 10.29000/rumelide.835421.
\end{abstract}

\section{Öz}

Akademik yazma, araştırma sürecini ve sonuçları belgeleyip ileten bir araç olmakla birlikte deneme, bildiri, araştırma ödevi ve bilgilendirme yazısı gibi türler üzerinden öğrencileri araştırma raporu yazmaya hazırlayan bir etkinlik olarak tanımlanabilir. Üniversite öğrencilerine akademik yazma yeterliği kazandırmak amacıyla Yüksek Öğretim Kurulu eğitim fakültelerinde verilmekte olan Türk Dili II dersinin içeriğini akademik yazma eğitimine yönelik olarak yeniden düzenlemiştir. Bu araştırmada üniversite birinci sınıf öğretmen adaylarının akademik yazma eğitimine yönelik görüşleri belirlenmeye ve bunun yanında YÖK'ün belirlediği yeni içeriğin derste uygulanması sürecinde ortaya çıkan sorunlar, eksikler ve ihtiyaçlar belirlenmeye çalışılmıştır. Çalışma grubunu Lefke Avrupa Üniversitesi Eğitim Fakültesi bünyesindeki İngilizce Öğretmenliği, Okul Öncesi Öğretmenliği, Özel Eğitim Öğretmenliği, Sosyal Bilgiler Öğretmenliği bölümlerinde öğrenim gören 102 öğrenci oluşturmaktadır. Araştırma, nitel araştırma desenlerinden biri olan "durum çalışması" deseni kapsamında yürütülmüştür. Veri toplama aracı olarak yarı yapılandırılmış görüşme formu kullanılmıştır. Ön görüşmede öğretmen adaylarının dörtte üçü akademik yazma kavramının ne olduğunu bilmezken son görüşmede bu oran azalarak akademik yazma konusunu kavradıkları anlaşılmıştır. Akademik yazmayı bilimsel gelişme, akademik kariyer, mesleki ve bireysel gelişim açısından faydalı ve kıymetli bulduklarını ifade etmeleri, öğretmen adaylarının Türk Dili II dersinin ana içeriği olan akademik yazma eğitiminin önem ve gerekliliğini kavradıklarını göstermiştir. Ancak katılımcıların akademik yazma becerisi kazanmada zorluklar yaşadıkları, kendilerini yetersiz buldukları anlaşılmıştır. Katılımcılar Türk Dili II dersinde teorik ve pratik düzeyde akademik yazma becerisi kazanmaktadır. Bu derste kazandırılan bilgi ve becerinin güçlenmesi diğer derslerde deneme, makale, proje gibi yazma çalışmalarının sürdürülmesiyle sağlanabilir.

Anahtar kelimeler: Akademik yazma, akademik yazma eğitimi, yazma becerisi, Türkçe

\section{The opinions of prospective teachers on teaching academic writing}

\begin{abstract}
Academic writing is used to document and the communication of the method and findings of a piece of research. In the context of academic education, however, it may be viewed as an activity that prepares students for disciplinary writing of a research report, which is commonly taught through exercises in writing essays, research articles, informative papers, etc. The Council of Higher Education has made significant strides in the development of the curricula of the Turkish

Dr. Öğr. Üyesi, Yeditepe Üniversitesi, Eğitim Fakültesi, Türk Dili ve Edebiyatı Öğretmenliği-TKL birimi (İstanbul,Türkiye), aysegulergisi@gmail.com, ORCID ID: oooo-ooo1-9250-1256 [Araştırma makalesi, Makale kayıt tarihi: 23.09.2020-kabul tarihi: 20.12.2020; DOI: 10.29000/rumelide.835421]

2 Dr., Başkent Üniversitesi, Eğitim Fakültesi, Temel Eğitim Bölümü, Sınıf Öğretmenliği ABD (Ankara, Türkiye), ckozaneryenigul@baskent.edu.tr, ORCID ID: oooo-0003-3849-3843
\end{abstract}

Adres 
Language-II course within the scope of and in accordance with programs that are designed to improve the academic writing proficiency of Faculty-of-Education students. In this study, it was aimed to determine the opinions of the freshman students that are enrolled on a Faculty-ofEducation program about teaching academic writing and the implementation of the new content in the course as well as the relevant problems, deficiencies and needs. The study group consists of 102 students that are enrolled in the English Language Teaching, Preschool Teaching, Special Education Teaching, and Social Studies Teaching Departments at the Fazll Küçük, Faculty of Education, European University of Lefke. The research was conducted within the scope of "case study" design, which is one of the qualitative research designs. A semi-structured interview form was used for data collection. Results from preliminary interviews revealed that three-quarters of the students did not understand the concept of academic writing; however, this ratio decreased by the end of the program, which is indicative of a successful program of study. Prospective teachers participating in the study stated that they find academic writing important with the thought that it will contribute to their education and profession; and that it will benefit them during their postgraduate education. They were thus found to be exhibiting a positive attitude towards the academic writing course, in general, by the end of the course. However, we observed that the participants found themselves inadequate with regards to experience in academic writing and, indeed, writing in general. The majority of the participants acquired sufficient theoretical and practical knowledge about academic writing skills in this course. Strengthening this knowledge and skills can be achieved by continuing writing activities such as essays, articles and projects in other curses.

Keywords: Academic writing, teaching academic writing, writing skills, Turkish language

\section{Giriş}

Bireyin kendini yazı aracılığıyla anlatabilme kabiliyeti olan yazma becerisi; konuşma, dinleme, okuma gibi dil becerileri arasında en zor olanıdır. Yazma becerisi diğer dil becerilerine, sözcük dağarcığına, dil duyarlılı̆̆ına, düşünme, gözlem ve araştırma yapma ve düzenli yazma çalışmalarına bağlı olarak gelişir. Yazma becerisinin kazandırıldığı ilk eğitim kademesinde yazma; cümle, paragraf ve metin boyutunda gerçekleştirilirken (Coşkun, 2011, s. 45) yükseköğretimde bu uygulamalar yerini deneme, makale, araştırma raporu gibi ileri amaçlı yazmaya bırakır.

Yazma becerisine odaklanan araştırmalarda işlevsel yazma, edebî yazma ve akademik yazma olmak üzere üç tip yazma becerisi olduğu kabul edilir (Aydın, 2015). İlk grubu dilekçe, mektup, tutanak ve özgeçmiş gibi uygulamaları içeren yazılar, ikincisini yaratıcılık ve üsluba dayalı olarak yazılan deneme, anı, gezi, öykü, roman, tiyatro gibi yazılar oluşturur. Akademik yazma ise bilimsel araştırmalar üzerinde temellenen makale, tez, proje gibi oldukça üst düzey yazma becerilerini içeren bir alan olarak diğerlerinden ayrılır.

Akademik yazmanın ne olduğuna dair çeşitli tanımlar yapılmıştır. Whitaker’a (2009) göre, akademik yazma, üniversite dersleri için yazılan yazılardır. Akademik yazıların bildiri, araştırma ödevi, dönem ödevi, tartışma ödevi, analiz ödevi, bilgilendirme yazısı gibi farklı adları olsa da bu tarz yazıların aynı amaç ve ilkeleri vardır. Monippally ve Pawar'a (2010) göre akademik yazma, araştırma sürecini ve araştırma sonuçlarını belgeleyip ileten bir araçtır. Bahar (2014) ise, akademik yazmayı bilimsel araştırmanın raporlaştırılması süreci yani araştırmanın metinleştirilmesi olarak görür. Akademik yazma bu tanımlarda üniversitelerde öğrenciye akademik yazma becerisi kazandırmak için yazdırılan yazılar ve bilimsel araştırmanın yazıya dökülmesi olarak iki şekilde belirginleşir. Öğrenci ödevlerinden

\footnotetext{
Adres $\mid$ Address

İstanbul Medeniyet Üniversitesi, Eğitim Bilimleri Fakültesi, Türkçe İstanbul Medeniyet University, Faculty of Education Sciences, ve Sosyal Bilimler Eğitimi Bölümü, Türkçe Eğitimi ABD Cevizli $\quad$ Turkish and Social Scinces Education, Turkish Language Teaching Kampüsü, Kartal-İstanbul/TÜRKIYE $\quad$ Education, Cevizli Campus, Kartal-İstanbul /TURKEY e-posta: editor@rumelide.com 1 e-mail: editor@rumelide.com
} 
bilimsel raporlara kadar geniş bir yelpaze oluşturan akademik yazılar; yeni bir kuram ortaya atmak, var olan olay ve durumları açıklamak ve karşılaştırmak, tarihsel analizler yapmak, deneysel ya da tarama yoluyla tespit edilen bilgileri sunmak amacıyla yazılır (Aydın, 2015). Problem çözmede bilimsel yöntemler kullanma, araştırma ve incelemeler yoluyla kanıtlara dayalı olarak yorum ve genellemeler yapma bilimsel bilgiyi kuran unsurlardır. Bilim, bilimsel araştırmalar neticesinde elde edilen bilginin standart kurallara bağlanarak yazı yoluyla muhatap kitleye ulaştırılması sayesinde geliştiğine göre, bilimin yuvası sayılabilecek üniversitelerde akademik yazmanın genel ilke ve esaslarının öğrenciye öğretilmesi gerekir.

Akademik yazma eğitiminde önce bilgi ve beceri kazandırma sonra bu becerinin yetkinleştirilmesi şeklinde iki aşamalı bir yol takip edilebilir. Bilgi ve beceri kazandırma sürecinde akademik yazma ve akademik dilin kurallarını öğretme gibi hedefler belirlenebilir. Wang (2012) akademik yazmanın temeline sözcük bilgisi ve sözcük seçiminin konulması gerektiğini çünkü sözcük dağarcığı gelişmiş bireylerin daha iyi yazabildiğini ifade eder. Akademik yazma, dil yeterliliği isteyen, bir amaca ve sürece dayalı, düşünce temelli ve kurallı bir yazmadır (Tok, 2013). Bu dil elbette, günlük konuşma dilinden farklı işlevleri olan, genellikle eğitim hayatında kullanılan, bilginin ve teknik terimlerin yön verdiği, üst düzey düşünme becerilerinin dâhil olduğu, nesnel nitelikli bir dildir (Sarıkaya, 2020). Bu dilin gelişim sürecinde okuma, dinleme, konuşma ve yazma becerilerine odaklanılır (Chamot ve O’Malley, 1994); yazma becerisinin gelişiminde okumanın kayda değer bir etkisi olduğuna vurgu yapılır (Koçak, 2005; Özdemir 2011; Göçer 2013). Bu sebeple öğrencinin okuma alışkanlıklarını güçlendirecek bir süreç gözetilmesinin yanında temel dilbilgisi ve yazım kurallarının da titizlikle öğretilmesi gerekir. Çünkü akademik yazmada noktalama işaretleri ve gramer kuralları netliği koruyan ve ifadede belirsizliği önleyen sistemlerdir. Düşüncelerin açık ve net bir şekilde ifade edilmesi, her zaman noktalama ve dilbilgisi kurallarına bağlıdır (Bowker, 2007).

Akademik yazma bir sorunun tespiti, planlama, teknik kuralları uygulama, sürekli araştırma yapma ve yazma gibi bir sürece tabidir (Aydın, 2015). Sorunun çözümüne yönelik temel ilkeler, teoriler, felsefeler, kavramlar ve diğer soyut fikirler incelendikten sonra bu bilgi organize edilerek resmi bir düzen ve yapı çerçevesinde yazıya dökülür. Giriş bölümünde konunun/sorunun doğası hakkında okuyucu bilgilendirilir, gelişme bölümünde sorun incelenip tartışılır, görüşler ayrıntılı verilir ve ulaşılan sonuçlar belirtilir. Sonuç bölümü, ele alınan konuyu çevreleyen çıkarımlardan oluştuğu gibi gelecek çalışmalara da ışık tutar. (Bowker, 2007). Ayrıca akademik yazmada dikkatli bir bilimsel üslup kullanarak kesin hükümler vermek yerine sebepler ve kanıtlar ileri sürerek belli sonuçlara varılır (Gillett, Hammond ve Martala, 2009). Dolayısıyla, akademik yazmanın temelinde akademik dil ve anlatım kurallarına titizlikle uyma, konuya özgü terim ve kavramlara yer verme, yapısal kurallara riayet etme, nesnel bakış açısını koruma, açıklayıcı ve ikna edici bir tutumla, düşünceleri anlaşılır bir düzende sunma, önceki çalışmalardan elde edilmiş bilgilere referans yapma gibi esaslar yer almaktadır (Whitaker, 2009; Hartley, 2008; Tompkins, 2009; Ekmekçi ve Konaç, 2009). Bu esaslar anlatım, uygulama, alıştırma gibi yöntem ve tekniklerle sunulup öğrenciye bilgi ve beceri kazandırıldıktan sonra lisans eğitimi boyunca sürdürülecek makale ve rapor yazma faaliyetleriyle akademik yazmada olgunlaşma sağlanabilir.

Yükseköğretim Kurulu 2018-2019 eğitim-öğretim yllından itibaren geçerli olmak üzere üniversitelerin eğitim fakülteleri bünyesindeki bütün programların müfredatlarında önemli değişiklikler yapmıştır. $\mathrm{Bu}$ çerçevede öğrenciye birinci sınıfta okutulan Türk Dili II dersinin müfredatı akademik yazma eğitimi konularından oluşacak şekilde düzenlenmiş (YÖK, 2017a) ve içerikte şu maddelere yer verilmiştir: "Akademik dil ve yazının özellikleri; akademik yazılarda tanım, kavram ve terimlerden

\footnotetext{
Adres $\mid$ Address

İstanbul Medeniyet Üniversitesi, Eğitim Bilimleri Fakültesi, Türkçe ve Sosyal Bilimler Eğitimi Bölümü, Türkce Eğitimi ABD Cevizli Turkish and Social Scinces Education, Turkish Language Teaching Kampüsü, Kartal-İstanbul/TÜRKIYE $\quad$ Education, Cevizli Campus, Kartal-İstanbul /TURKEY e-posta: editor@rumelide.com $\mid$ e-mail: editor@rumelide.com
} 
yararlanma; nesnel ve öznel anlatım; akademik metinlerin yapısı ve türleri (makale, rapor ve bilimsel özet vb.); iddia, önerme yazma (bir düşünceyi doğrulama, savunma ya da karşı çıkma); bilimsel raporların ve makalelerin biçimsel özellikleri; rapor yazmanın basamakları; açıklama, tartışma, metinler arası ilişki kurma, kaynak gösterme (atıf yapma ve dipnot gösterme, kaynakça oluşturma); başlık yazma, özetleme, anahtar kelime yazma; bilimsel yazılarda dikkat edilecek etik ilkeler; akademik metin yazma uygulamaları" (YÖK, 2017b).

Alanyazın incelendiğinde İngilizce akademik yazma becerisi ve eğitimi ile ilgili pek çok araştırmanın yapıldığı, buna karşılık Türkçe akademik yazmaya yönelik çalışmaların çok az olduğu görülmüştür. Türkçe akademik yazma eğitimiyle ilgili çalışmaların çoğunda lisansüstü öğrenciler ile öğretim elemanları çalışma grubu olarak seçilmiştir. Aslan (2010) Türkçe eğitimi programlarında lisansüstü öğrenim gören öğrencilerin akademik öz yeterliklere ilişkin görüşlerine; Can ve Ceyhan (2015) eğitim bilimlerinde lisansüstü öğrencilerin bilimsel rapor yazma ve yayınlama konusundaki görüşlerine; Kan ve Gedik (2016) Türkçe eğitiminde yüksek lisans tezi yazanların akademik yazma ve tez oluşturma sürecine ilişkin görüşlerine; Tok ve Gönülal (2016) öğretim elemanlarının yazma sürecinde yaşadıkları zorluklara odaklanmışlardır. Lisans kademesindeki öğrencilerin akademik yazma eğitimi, beceri ve yeterlilikleri ile ilgili sadece iki çalışmadan birinde Bayat (2014) öğretmen adaylarının eleştirel düşünme düzeyleri ile akademik yazma başarıları arasındaki ilişkiyi saptamak için öğrencilerin eleştirel düşünme ve akademik yazma düzeyleri arasında anlamlı bir ilişki olup olmadığını, bu düzeylerin, onların öğrenim gördükleri anabilim dalına göre farklılaşıp farklılaşmadığını anlamaya çalışmıştır. Diğerinde ise Aydın (2015) Türk dili ve edebiyatı öğrencilerinin yansıtıcı öğretim uygulamalarının akademik yazma başarı ve tutumlarına etkisini incelemiştir. Bu çalışmada da lisans birinci sınıf öğrencilerinin Türkçe akademik yazma eğitimine odaklanarak alanyazına katkıda bulunulması düşünülmektedir. Genel amacı, öğretmen adaylarının Türkçe akademik yazma eğitimine yönelik görüşlerini belirlemek olan bu çalışma, yeni müfredatın uygulanması, öğrencilerin sorunları ve ihtiyaçları ile ilgili dönüt vereceğinden alan için önemli olduğu düşünülmektedir. Bu çalışmanın amacı, öğretmen adaylarının Türk Dili II dersinin içeriğinde yer alan akademik yazma konularına ve önemine ilişkin görüşlerinin belirlenmesidir. Bu amaç doğrultusunda:

1. Öğretmen adaylarının dönem başında Türk Dili II dersinin içeriği olan akademik yazma konusuna yükledikleri anlamlar nelerdir?

2. Öğretmen adaylarının dönem sonunda Türk Dili II dersinin içeriği olan akademik yazma konusuna yükledikleri anlamlar nelerdir?

3. Öğretmen adaylarının dönem başında Türk Dili II dersinin içeriği olan akademik yazma konusunu önemli bulma durumları nedir?

4. Öğretmen adaylarının dönem sonunda Türk Dili II dersinin içeriği olan akademik yazma konusunu önemli bulma durumları nedir?

5. Öğretmen adaylarının Türk Dili II dersinin içeriği olan akademik yazma konusunda kendini yeterli bulma durumları nedir?

6. Türk Dili II dersinin içeriği olan akademik yazma eğitiminin öğretmen adaylarına kazandırdıkları nelerdir?

7. Öğretmen adaylarının Türk Dili II dersinde yapılan akademik yazma ile ilgili etkinliklere yönelik görüşleri nelerdir?

8. Öğretmen adaylarının tartışmacı metin yazma etkinliğinde öğrendikleri bilgi ve becerileri aktarım durumları nedir? sorularına cevap aranmıştır.

\footnotetext{
Adres Address

İstanbul Medeniyet Üniversitesi, Eğitim Bilimleri Fakültesi, Türkçe $\quad$ İstanbul Medeniyet University, Faculty of Education Sciences, ve Sosyal Bilimler Eğitimi Bölümü, Türkçe Eğitimi ABD Cevizli Turkish and Social Scinces Education, Turkish Language Teaching Kampüsü, Kartal-İstanbul/TÜRKIYE $\quad$ Education, Cevizli Campus, Kartal-İstanbul /TURKEY e-posta: editor@rumelide.com $\mid$ e-mail: editor@rumelide.com
} 


\section{Yöntem}

\section{Araștırmanın modeli}

Araştırma, nitel araştırma desenlerinden biri olan "durum çalışması" deseni kapsamında yürütülmüştür. Bu yöntem birçok durumda bireysel, örgütsel ve sosyal olaylara ilişkin bilgilerimize katkıda bulunmak için kullanılmaktadır (Yin, 2003). Durum çalışmasının en temel özelliği bir ya da birkaç durumun derinliğine araştırılmasıdır. Araştırmacı, duruma yönelik etkenlerin ilgili durumu nasıl etkilediğine odaklanır (Yıldırım ve Şimşek, 2013). Bu araştırmada durum çalışmasının bir türü olan programın etkilerine dayalı durum çalışması kullanılmıştır. Program etkilerine dayalı durum çalışmaları uygulanan programın etkisini belirleyebilir, başarı ve başarısızlık nedenleri hakkında çlkarım sağlayabilir (Davey, 1991).

\section{Çalışma grubu}

Araştırmanın çalışma grubunu 2018-2019 Akademik yılında, Kuzey Kıbrıs Türk Cumhuriyeti, Lefke Avrupa Üniversitesi Dr. Fazıl Küçük Eğitim Fakültesinde öğrenim gören lisans birinci sınıf öğrencileri oluşturmuştur. Çalışma grubu, amaçlı örnekleme yöntemlerinden biri olan tipik durum örneklemesine (Büyüköztürk vd., 2008) göre belirlenmiştir. Çalışma grubuna yönelik veriler Tablo 1'de verilmiştir.

\begin{tabular}{lll}
\hline Bölümler & Frekans $(\boldsymbol{f})$ & Yüzde (\%) \\
\hline Okul öncesi öğretmenliği & 39 & 38,23 \\
Özel eğitim öğretmenliği & 32 & 31,37 \\
İngilizce öğretmenliği & 25 & 24,50 \\
Sosyal bilgiler öğretmenliği & 6 & 5,88 \\
\hline Toplam & 102 & 100
\end{tabular}

Tablo 1: Öğretmen adaylarının bölümlere göre dağılımı

\section{Veri toplama araçları}

Araştırmada veri toplama aracı geliştirilirken ilk olarak alanyazın incelenmiştir (Akgün, 2012; Alabaş, 2016). Bu doğrultuda veri toplama aracı olarak yarı yapılandırılmış görüşme formu ve gözlem yöntemi kullanılmıştır. Yarı yapılandırılmış görüşme formunda yer alan sorular araştırmanın alt amaçları temel alınarak oluşturulmuştur. Araştırma sorularının amaca uygun olup olmadığını ve anlaşlabilirliğini belirlemek amacıyla, alanda çalışan 2 uzmanın görüş ve onayları alınmıştır. 2018-2019 Akademik yılı başlangıcında sorulan ön görüşme soruları öğretmen adaylarının akademik yazma konusunda bilgi sahibi olma durumları, akademik yazma konusunu önemli bulma durumları ve dersin kendilerine ne kazandıracağına dair düşüncelerini belirlemeye yönelik açık uçlu sorulardan oluşmuştur. Dönem sonunda uygulanan yarı yapılandırılmış görüşme formunda ise, akademik yazmaya yükledikleri anlamlara, akademik yazma konusundaki yeterliliklerine ve süreçte yapılan etkinliklere ilişkin sorular bulunmaktadır. Araştırmada bir diğer veri toplama aracı gözlem notlarıdır. Gözlem notları elde edilmiş diğer bilgilerin desteklenmesinde veya tamamlanmasında kullanılır (Büyüköztürk vd., 2008). Öğretmen adaylarının ders içi yazma etkinliklerine yönelik, sınıf ortamında araştırmacı tarafından notlar alınmış ve değerlendirilmiştir. Not alma gözleme dayalı çalışmalarda en sık kullanılan kaydetme yöntemidir. Araştırmacı kendi geliştirdiği kısaltmalar yoluyla, gözlem sürecinde mümkün olduğunca tanımlayıcı not almaya çalışır (Yıldırım ve Şimşek, 2016). Aslında, her türlü veri toplama işlemi, bir tür

\footnotetext{
Adres $\mid$ Address

İstanbul Medeniyet Üniversitesi, Eğitim Bilimleri Fakültesi, Türkçe İstanbul Medeniyet University, Faculty of Education Sciences, ve Sosyal Bilimler Eğitimi Bölümü, Türkce Eğitimi ABD Cevizli Turkish and Social Scinces Education, Turkish Language Teaching Kampüsü, Kartal-İstanbul/TÜRKIYE $\quad$ Education, Cevizli Campus, Kartal-İstanbul /TURKEY e-posta: editor@rumelide.com 1 e-mail: editor@rumelide.com
} 
gözlemdir (Karasar, 2012). Akademik yazmaya ilişkin etkinlikleri değerlendirmek amacıyla da araştırmacılar tarafından değerlendirme kriterleri oluşturulmuştur (Tablo 9).

\section{Verilerin analizi}

Çalışmada elde edilen veriler betimsel analiz ile çözümlenmiş, frekans analizi ile sayısal ve oransal sınıflama yapılmıştır. Betimsel analizde veriler, önce sistematik ve açık biçimde betimlenir, daha sonra yapılan bu betimlemeler açıklanır, yorumlanır, ayrıca bireylerin görüşlerini çarpıcı bir biçimde yansıtmak amacıyla doğrudan alıntılara sık sık yer verilir (Yıldırım ve Şimşek, 2013).

Veri analizinin ilk aşamasında, çalışmanın amacına uygun olmayan ve anlam ifade etmeyen görüşme formları araştırma kapsamından çıarılmıştır. Bu bağlamda 24 katılımcının görüşme formu analiz sürecine alınmamış, 78 öğretmen adayının görüşme formunun analizi yapılmıştır. İkinci olarak öğretmen adaylarının isimleri kullanılmadan her bir görüşme formuna numara verilmiş, katılımcılar için "K" kodu ve sıra numarası kullanılmıştır (Örneğin; K1, K2, K3). Öğretmen adaylarının görüşme sorularına verdikleri cevaplardan yola çlkarak kategoriler oluşturulmuştur. Kategoriler saptandıktan sonra, anlam birimleri bu kategorilere yerleştirilerek frekanslar saptanmıştır.

\section{Geçerlik ve güvenirlik}

Araştırmada iç geçerliği sağlamak için görüşme formlarından elde edilen veriler kodlanmış, doğrudan alıntılarla kodlar desteklenmiştir. Bulguların bütünlüğü araştırmacı tarafından sürekli kontrol edilmiştir. İçerik analizinde geçerlik amaçlar ve araçlar arasındaki uygunlukla ilgilidir (Bilgin, 2014). İç geçerlik başka bir anlamda doğruluk değerinin tartışılmasıdır. Çalışmanın bulgularının anlam taşıyıp taşımadığı, okuyucu açısından bir gerçekliğe sahip olup olmadığı iç geçerlik konusunu oluşturmaktadır (Miles ve Huberman, 1994). Ayrıca çalışmanın verileri araştırmacılar tarafından incelenerek karşılaştırılmış ve yorumlanmıştır.

Dış geçerliği sağlamak için, araştırma süreci yani veri toplama, uygulama ve analiz aşaması ayrıntılı açıklanmaya çalışılmıştır. Çalışmada elde edilen verileri kodladıktan sonra, katılımcıların cevaplarıyla belirlenen kategoriler birden fazla araştırmacı tarafından yorumlanmıştır. Araştırma sorularına verilen cevaplar için kontrol listesi oluşturulmuş ve listede her iki araştırmacının aynı ya da farklı alanlara görüş ve kategorileri eşleştirme durumuna göre güvenirlik belirlenmiştir. Liste karşlaştırılarak görüş birliği ve ayrılıklarının sayıları belirlendikten sonra çalışmanın güvenilirliği, "Güvenirlik= ((Görüş Birliği): (Görüş Birliği+Görüş Ayrıllğı)) x 100” formulü (Miles ve Hubermann, 1994) kullanılarak hesaplanmıştır. Bu doğrultuda katılımcıların akademik yazma konusuna yönelik görüşlerini oluşturan kategorilere yapılan güvenirlik analizinde, çalışmanın güvenilirliği \%93 olarak hesaplanmıştır.

İşlem şu şekilde ifade edilmiştir.

Güvenilirlik=((61): $(61+4)) \times 100=>$ Güvenirlilik=\% 93

\section{Türk Dili II dersinin işlenişi}

Dersin amacı, öğrenciye akademik yazmanın temel ilkelerini, akademik yazıların türlerini ve özelliklerini öğretme, öğrenciye bilgi ve beceri kazandırma olarak belirlenmiştir. Öğrenme çıtıları; bilimsel araştırmanın önemini ve basamaklarını bilme; bilimsel metin türlerini tanıyabilme ve onlardan faydalanabilme; bilimsel yazıların biçim ve içerik özelliklerini kavrayabilme; dipnot ve

\footnotetext{
Adres | Address

İstanbul Medeniyet Üniversitesi, Eğitim Bilimleri Fakültesi, Türkçe İstanbul Medeniyet University, Faculty of Education Sciences, ve Sosyal Bilimler Eğitimi Bölümü, Türkce Eğitimi ABD Cevizli Turkish and Social Scinces Education, Turkish Language Teaching Kampüsü, Kartal-İstanbul/TÜRKIYE $\quad$ Education, Cevizli Campus, Kartal-İstanbul /TURKEY e-posta: editor@rumelide.com 1 e-mail: editor@rumelide.com
} 
kaynak gösterme, atıf şekillerini tanıyabilme; bilimsel yazılarda dikkat edilecek etik ilkeleri bilme; Türkçeyi doğru ve etkili kullanabilme ve yazabilme olarak düzenlenmiştir. İlk derste yazma konusunda herhangi bir bilgi verilmeden "Bir kitabı okumak mı uyarlama filmini seyretmek mi istersiniz?" sorusu sorularak uyarlama filmin ne olduğu kısaca anlatılmış, konuyla ilgili bir tartışma metni yazmaları istenmiştir.

Dönem boyunca öğrenme çlktılarına uygun olarak konular şu sırayla anlatılmıştır: Bilimsel araştırmanın önemi ve basamakları; makale, tez, proje, kitap, editöre mektup, kitap inceleme gibi akademik yazı türleri hakkında bilgi verilerek yazı türleriyle ilgili örnekler gösterilmiştir. Özet çıkarma çalışmaları, cümle ve paragrafları birbirine bağlayan geçiş ifadeleri, öznel ve nesnel anlatım, açıklayıcı ve tartışmacı anlatım ile düşünceyi geliştirme yolları örneklerle anlatılmış, bu yollarla paragraf yazma çalışmaları yaptıılmıştır. Makale ve tezin tanımı, biçim ve içerik özellikleri, bölümleri anlatılıp örnek makale ve tezler yoluyla bu metinlerin özellikleri ve bölümleri kavratılmıştır. Literatür taramasının nasıl yapıldığı kütüphane modülü üzerinden gösterilerek alanlarıyla ilgili konularda makale taramaları ödev olarak verilmiştir. Bilimsel yazılarda doğrudan ve dolaylı alıntı şekilleri, kaynak gösterme konusu anlatılarak bilim dünyasında yaygın olarak kullanılan APA yazım sistemiyle ilgili çeşitli uygulamalar yapılmıştır. Bilimsel yayınlarda dikkat edilecek etik ilkeler ve bilimsel yanıltma biçimleri de anlatılarak konular tamamlanmıştır.

Dönem sonunda tartışmacı metin oluşturma etkinliği tekrar yapılmıştır. Bir tartışmacı metnin "iddia”, "karşı iddia" gibi temel unsurları vardır. İddia, tartışılan konu ile ilgili olarak yazarın savunduğu tez, yani temel düşüncedir. Bu tür yazılar konuyu açıklayıp iddia cümlesini yazarak başlatılır. Yazar, gerekçeler ve kanıtlar sunarak iddiasını sonuca bağlamaya çalışır (Coffin vd., 2005). Gözlem formuyla uygulanan bu yazma etkinliği sayesinde öğrencinin ders içeriğini anlama ve uygulamaya dökebilme düzeyi, konuları öğrenme durumları tespit edilmeye çalışılmıştır.

2018-2019 Akademik yll Bahar dönemi boyunca Türk Dili II dersinin yürütülmesinde iki büyük zorlukla karşılaşılmıştır. Birincisi dersin 70 kişilik kalabalık sınıflarda yürütülmesi ve dolayısıyla yazma etkinliklerinin sağlıklı bir zeminde işlememesi, ikincisi ise YÖK’ün belirlediği içeriği kapsayan teorik bir ders kitabının bulunmaması idi. Bu eksiklik, internet ortamında taranan makaleler ve ders notları yoluyla doldurulmuştur. Ancak eski Türk Dili kitaplarında öznel ve edebi nitelikli paragraflar yoğun olduğu için etkinliklerde kullanılacak akademik nitelikli metinler bulmak ve çalışma kâğıtlarına dönüştürmek güçlük yaratmıştır. Paragraf ve metin örnekleri için hem üst düzey sınav testlerindeki paragraflara müracaat edilmiş hem de makale ve tezlerden bölümler kullanılmıştır. Ancak öğrencinin bu örneklere ilgisi kolayca çekilememiştir; konu, terim ve kavramlara dair bilgisizlikleri dersin işlenişini zorlaştırmıştır. Öğrencinin alanına yönelik örnek metinler verilince daha etkili bir sonuç alındığı görülmüştür. Örneğin Özel Eğitim Bölümü öğrencileri otizmli çocuklarla yönelik metinleri, İngilizce Öğretmenliği Bölümü öğrencileri çift dillilik gibi dilsel metinleri ilgiyle okuyup anlamaya çalışmışlardır.

\section{Bulgular}

Araştırmanın bulguları, Türk Dili II dersinin içeriği olan akademik yazma konusuna ilişkin uygulanan veri toplama araçlarına göre şekillenmiştir. Tablo 2 ve Tablo 3 'te dersin ilk haftasında uygulanan araştırma sorularından elde edilen bulgular; Tablo 4, Tablo 5, Tablo 6, Tablo 7 ve Tablo 8'de dersin son haftasında uygulanan yapılandırılmış görüşme formundan elde edilen bulgular bulunmaktadır. $\mathrm{Bu}$ bölümde öğrencilerin sorulara verdiği cevaplar ve bu cevaplara dair gözlem ve değerlendirmelere yer

\footnotetext{
Adres $\mid$ Address

İstanbul Medeniyet Üniversitesi, Eğitim Bilimleri Fakültesi, Türkçe $\quad$ İstanbul Medeniyet University, Faculty of Education Sciences, ve Sosyal Bilimler Eğitimi Bölümü, Türkçe Eğitimi ABD Cevizli Turkish and Social Scinces Education, Turkish Language Teaching Kampüsü, Kartal-İstanbul/TÜRKIYE $\quad$ Education, Cevizli Campus, Kartal-İstanbul /TURKEY e-posta: editor@rumelide.com $\mid$ e-mail: editor@rumelide.com
} 
verilmiştir. Öğretmen adaylarının dönemin başında ve sonundaki tartışmacı metin yazma etkinlikleri sayesinde edindikleri bilgi ve becerileri aktarım durumları da Tablo 9’ da verilmiştir.

\section{Araştırmanın birinci alt problemine ilişkin bulgular ve yorum}

Dönem başında, öğretmen adaylarının Türk Dili II dersinin içeriği olan akademik yazmaya yükledikleri anlamları belirlemek amacıyla "Akademik yazma konusunda bilgi sahibi misiniz? Açıklayınız." sorusu sorulmuştur. Bu soruya katılımcılar tarafından verilen cevaplar ve elde edilen verilerin frekans ve yüzde değerleri Tablo 2'de verilmiştir.

\begin{tabular}{lll}
\hline İfadeler & $\boldsymbol{f}$ & $\mathbf{\%}$ \\
\hline Bilgi sahibi değil & 62 & 79,49 \\
Bilimsel bilginin yazıya aktarılması & 13 & 16,67 \\
Yeterince bilgi sahibi değil & 2 & 2,56 \\
Bilimsel dilin kullanımı olarak görme & 1 & 1,28 \\
\hline Toplam & 78 & 100 \\
\hline
\end{tabular}

Tablo 2: Öğretmen adaylarının dönem başında Türk Dili II dersinin içeriği olan akademik yazma konusuna yükledikleri anlamlar

Özel eğitim öğretmenliği bölümünden 28 , Okul öncesi öğretmenliği bölümünden 17 , İngilizce öğretmenliği bölümünden 14, Sosyal bilgiler öğretmenliği bölümünden 3 olmak üzere toplam 62 katılımcı akademik yazma konusunda bilgi sahibi olmadığını belirtmiştir. Katılımcılardan (K21) "Bilgi sahibi değilim. Okul döneminde hiç akademik yazı yazmadım. Nasıl yazılması gerektiği konusunda da hiç fikrim yok"; (K46) "Lisede gerekli kurumlara dilekçe vb. şeyler yazmamız öğretildi. Bunun dışında bir bilgim yok"; (K65) "Pek söylenemez. Akademik yazı olarak öğrenim hayatım boyunca kompozisyon, dilekçe ve mektup dışında bir şey yazmadım. Akademik yazma denilince aklıma kompozisyon, dilekçe mektup, deneme geliyor"; (K75) "Kısa, öz, gereksiz bilgilerden kaçınarak net ifadeler ile yazılan resmi yazılardır" şeklinde görüş belirtmiştir. Buna benzer görüşlerin çokluğu öğretmen adaylarının akademik yazmaya ilişkin bazı kavram yanılgılarının olduğunu, akademik yazmayı dilekçe, mektup gibi işlevsel yazılarla deneme ve kompozisyon gibi öznel nitelikli, bireysel izlenimlerin öne çıtı̆̆ı, öğrenciyi ortaöğretim düzeyinde yazmaya alıştıran üsluba dayalı yaratıcı yazma çalışmalarıyla karıştırdıkları ortaya çıkmıştır. Böylece bu kategoride cevap veren katılımcıların çoğunun akademik yazma konusuna yabancı oldukları anlaşılmıştır.

Özel eğitim öğretmenliği bölümünden 6 , İngilizce öğretmenliği bölümünden 6 , Okul öncesi öğretmenliği bölümünden 1 olmak üzere toplam 13 katılımcı akademik yazmayı, bilimsel bilginin yazıya aktarılması olarak tanımlamıştır. Bu kategoriye ait görüşler şu şekildedir: (K12) "Tam anlamıyla bilmesem de genel hatlarıyla biliyorum. Örneğin, öznel anlatımla yazılmayacağı, bilimsel verilerden yararlanılarak yazıldığını, giriş, gelişme sonuç şeklinde yazıldığını biliyorum"; (K2O) "Akademik yazma, bir konu hakkında araştırma yapılarak, bilimsel verilere bakılarak yazılan açıklayıcı yazılardır”; (K33) "Akademik yazma, bir konu hakkında bilimsel verilere dayalı yazmadır. Aktarılmak istenen bilginin TDK yazım ve noktalama kurallarına uygun olması gereklidir” şeklinde görüş belirtmişlerdir.

Katılımcılardan ikisi ise yeterince bilgi sahibi olmadığını belirtmiştir: İngilizce öğretmenliği bölümünden bir katılımcı (K68) "Yanılmıyorsam makale oluyor. Makale akademik yazmanın bir alt dalı olabilir. Fazla bilgi sahibi değilim açıçcası” demiştir. Özel eğitim öğretmenliği bölümünden de bir

\footnotetext{
Adres Address

İstanbul Medeniyet Üniversitesi, Eğitim Bilimleri Fakültesi, Türkçe İstanbul Medeniyet University, Faculty of Education Sciences, ve Sosyal Bilimler Eğitimi Bölümü, Türkce Eğitimi ABD Cevizli Turkish and Social Scinces Education, Turkish Language Teaching Kampüsü, Kartal-İstanbul/TÜRKIYE $\quad$ Education, Cevizli Campus, Kartal-İstanbul /TURKEY e-posta: editor@rumelide.com 1 e-mail: editor@rumelide.com
} 
katılımcı (K10) "Yeterince bilmiyorum, ama bilimsel bir konunun ciddi bir şekilde anlatıldığı yazma olabilir.” demiştir. Özel eğitim öğretmenliğinden bir katılımcı ise, $\left(\mathrm{K}_{7}\right)$ "Akademik yazmada bilimsel bir dil kullanılır.” şeklinde cevap vermiştir. Görüldüğü gibi yeterince bilgi sahibi olmadığının söyleyen 2 katılımcı tahmini olarak, bilimsel dilin kullanımı olarak gören 1 katılımcı ise akademik yazmanın sadece bir unsuruna odaklanarak akademik yazmaya az da olsa aşina olduğunu göstermiştir.

Sonuç olarak, katılımcıların \%79,49'unun akademik yazmaya yabancı olduğu \%20,51’inin ise akademik yazma hakkında bilgi sahibi olduğu ortaya çıkmıştır.

\section{Araştırmanın ikinci alt problemine ilişkin bulgular ve yorum}

Dönem sonunda öğretmen adaylarının akademik yazmaya yönelik tanımlarını belirlemek amacıyla "Akademik yazma nedir? Açıklayınız." sorusu sorulmuştur. Bu soruya katılımcılar tarafından verilen cevaplar ve elde edilen verilerin frekans ve yüzde değerleri Tablo 3’te verilmiştir.

\begin{tabular}{lll}
\hline İfadeler & $\boldsymbol{f}$ & $\mathbf{\%}$ \\
\hline Bilimsel araştırma sürecinin yazıya aktarılması & 20 & 25,64 \\
Bilimsel bir üslupla yazma & 19 & 24,36 \\
Objektif ve kanıtlanabilir yazı & 11 & 14,10 \\
Bilimsel yazı & 11 & 14,10 \\
Problem odaklı bilimsel yazı & 7 & 8,97 \\
Uzman kişiler tarafından yazılan yazı & 5 & 6,41 \\
Fikri yok & 5 & 6,41 \\
\hline Toplam & 78 & 100 \\
\hline
\end{tabular}

Tablo 3: Öğretmen adaylarının dönem sonunda Türk Dili II dersinin içeriği olan akademik yazma konusuna yükledikleri anlamlar

Okul öncesi öğretmenliği bölümünden 5 katılımcı akademik yazmanın ne olduğuna dair herhangi bir görüş bildirmezken Özel eğitim öğretmenliği bölümünden 26, Okul öncesi öğretmenliği bölümünden 26, İngilizce öğretmenliği bölümünden 17 , Sosyal bilgiler öğretmenliği bölümünden 4 olmak üzere toplam 73 katılımcı 6 kategoride akademik yazmanın tanımını yapmaya çalışmıştır. Akademik yazmayı bilimsel araştırma sürecinin yazıya aktarılması olarak gören 20 katılımcıdan birkaçı (K3) "Bilimsel araştırma basamaklarının takip edildiği, nesnel anlatımın kullanıldığı, belirli bir konu ve düzen içinde ilerleyen bir süreçtir. Kaynakçanın bulunduğu, yazılanların bir kaynağa dayandırıldığı yazılardır”; (K72) "Bilimsel araştırma ve hipotezlerin tutarlılığı, herkes tarafından kabul edilen bilgilerin yazılmasıdır" şeklinde bilimsel araştırma sürecine vurgu yaparak görüşünü bildirmiştir. Akademik yazmayı bilimsel bir üslupla yazma olarak sınırlayan 19 katılımcıdan birkaçı (K21) "Bilimsel bir dil ile yazılan yazılardır"; (K40) “Akademik yazma bir konu hakkındaki fikirlerin akademik ve kurallı bir dille yazılmasıdı" demiştir. Akademik yazmayı objektif ve kanıtlanabilir yazı olarak ifade eden 11 katılımcıdan birkaçı (K28) "Kanıtlanabilirliği açısından nesnel olan, daha çok herhangi bir iddia ispatlamaya çalışan yazılardır"; (K62) "Bilimsel bir konuyu nesnel ve planlı bir şekilde yazmaktır" şeklinde görüş bildirmişlerdir. Akademik yazmayı sadece bilimsel yazı olarak kategorize eden 11 katılımcıdan birkaçı (K45) "Akademik yazma, bilimsel bir konu hakkında yazılan yazılardır"; (K68) "Bir konu hakkında kurallı ve bilimsel olarak yazılan yazılardır" şeklinde görüş belirtmiştir. Katılımcıların 7'si akademik yazmayı problem odaklı bilimsel yazı olarak tanımlamıştır: (K27) "Akademik yazma bir konu hakkında veya bir problem üzerine yazılan bilimsel, kanıtlanmış araştırmaları içeren yazılardır"; (K31) "Bir problemden yola çıkarak derin, kapsamlı sorunun

\footnotetext{
Adres $\mid$ Address

İstanbul Medeniyet Üniversitesi, Eğitim Bilimleri Fakültesi, Türkçe İstanbul Medeniyet University, Faculty of Education Sciences, ve Sosyal Bilimler Eğitimi Bölümü, Türkce Eğitimi ABD Cevizli Turkish and Social Scinces Education, Turkish Language Teaching Kampüsü, Kartal-İstanbul/TÜRKIYE $\quad$ Education, Cevizli Campus, Kartal-İstanbul /TURKEY e-posta: editor@rumelide.com 1 e-mail: editor@rumelide.com
} 
çözümünü amaçlayan yazllardır" ifadelerini kullanmıştır. 5 katılımcı ise akademik yazmanın uzman kişiler tarafından yazılan yazılar olduğunu belirtmiştir: (K34) "Akademisyenlerin veya konu hakkında bilgisi olan kişilerin yazdığı türdür"; (K55) "Belirli bir görüşe dayalı belirli dergilerde konunun uzmanlarının yazdığı yazılardır” olarak tanımlamıştır.

Bu görüşlerden yola çıkarak söylenebilir ki, dönem başında öğretmen adaylarının sadece \%20,51’i akademik yazma hakkında bilgi sahibi iken dönem sonunda bu değer \%93,59'a yükselmiş ve akademik yazma konusuna yükledikleri anlamlar ve yaptıkları tanımlar olumlu şekilde değişiklik göstermiştir.

\section{Araştırmanın üçüncü alt problemine ilişkin bulgular ve yorum}

Türk Dili II dersinin içeriği olan akademik yazma konusuyla ilgili öğretmen adaylarına dönem başında, "Akademik yazma konusunu önemli buluyor musunuz? Gerekçelerini açıklayınız." sorusu sorulmuştur. Bu soruya katılımcılar tarafından verilen cevaplar ve elde edilen verilerin frekans ve yüzde değerleri Tablo 4'te verilmiştir.

\begin{tabular}{lcc}
\hline İfadeler & $\boldsymbol{f}$ & $\mathbf{\%}$ \\
\hline Meslek hayatına katkısı olacağı için önemli bulma & 18 & 23,08 \\
Eğitim hayatına katkı sağlayacağı için önemli bulma & 16 & 20,51 \\
Fikri yok & 16 & 20,51 \\
Lisansüstü eğitime katkısı olacağı için önemli bulma & 7 & 8,97 \\
Önemli olmadığını düşünme & 7 & 8,97 \\
Lisans programının gereği olarak düşünme & 6 & 7,69 \\
Resmi yazışmalarda kullanıldı̆̆ı için önemli bulma & 4 & 5,13 \\
Ĕ̆itim ve meslek hayatına katkı sağlayacağı için önemli bulma & 4 & 5,13 \\
\hline Toplam & 78 & 100 \\
\hline
\end{tabular}

Tablo 4: Öğretmen adaylarının dönem başında Türk Dili II dersinin içeriği olan akademik yazma konusunu önemli bulma durumları

Öğretmen adayları çeşitli gerekçelerle akademik yazma konusunu önemli bulduklarını belirtmişlerdir. Özel eğitim öğretmenliği bölümünden 31, İngilizce öğretmenliği bölümünden 12, Okul öncesi öğretmenliği bölümünden 6 , Sosyal bilgiler öğretmenliği bölümünden 2 olmak üzere toplam 51 katılımcı meslek hayatına, eğitim hayatına, lisansüstü eğitimine katkı sağlaması, lisans programının gereği olarak görülmesi gibi kategorilerde olumlu görüş bildirmiştir. Meslek hayatına katkısı olacağı için akademik yazma konusunu önemli bulduğunu ifade eden 18 katılımcıdan birkaçı (K32) "Evet gerekli buluyorum. Çünkü ben mezun olduktan sonra bir eğitmen olarak topluma karışacağım ve öğretmen olarak çalışacağım”; (K67) "Tabii ki önemli buluyorum. Mezun olduktan sonra mesleğimi icra etmemde bana katkısı olacağını düşünüyorum"; (K73) "Önemli buluyorum. Çünkü hayatımız ve en önemlisi mesleğimiz öğretmenlik olduğu için her anlamda önemi var.” şeklinde görüşlerini ifade etmiştir. Eğitim hayatına katkı sağlayacağı için akademik yazma konusunu önemli bulduğunu ifade eden 16 katılımcıdan birkaçı (K14) "Evet olması gereken bir konu. Üniversite öğrencilerinin bu dersi görmesi gerektiğini düşünüyorum”; (K28) "Düzenli ve anlaşılır bir şekilde yazmak karşı tarafin anlamasını kolaylaştırır. Tez yazımı gibi konularda kolaylık sağlar”; (K78) “Önemli buluyorum. Çünkü lisede akademik yazmaya dair bir ders almadım ve bu yazı türü önemli, eğitim hayatımda ilerleyen zamanlarda lazım olacaktır.” şeklinde görüş bildirmiştir. Hem eğitim hem de meslek hayatına katkı

\footnotetext{
Adres $\mid$ Address

İstanbul Medeniyet Üniversitesi, Eğitim Bilimleri Fakültesi, Türkçe İstanbul Medeniyet University, Faculty of Education Sciences, ve Sosyal Bilimler Eğitimi Bölümü, Türkce Eğitimi ABD Cevizli Turkish and Social Scinces Education, Turkish Language Teaching Kampüsü, Kartal-İstanbul/TÜRKIYE Education, Cevizli Campus, Kartal-İstanbul /TURKEY e-posta: editor@rumelide.com 1 e-mail: editor@rumelide.com
} 
sağlayacağı için konuyu önemli bulduğunu belirten 4 katılımcıdan biri (K1) "Evet. Çünkü hem üniversite hayatımda hem de iş hayatımda akademik yazma konusunda bilgi sahibi olursam benim için çok avantajlı bir şey olacağını düşünüyorum” şeklinde görüş belirtmiştir. Lisansüstü eğitime katkısı olacağı için akademik yazmayı önemli bulduğunu ifade eden 7 katılımcıdan birkaçı (K9) "Akademik yazma konusunu önemli buluyorum çünkü ileriki dönemlerde yüksek lisans gibi eğitimlere katkı sağlayabilir"; (K13) "Önemli buluyorum çünkü mesleğimde yükselmek istediğim zaman ve yazacağım tezlerde faydalı olacak bir konu" şeklinde görüş belirtmiştir. Lisans programının gereği olarak gördüğü için konunun önemli olduğunu söyleyen 6 katılımcıdan biri (K4) "Müfredatta bize okutulması kabul görülen her konunun belirli alanlar ve durumlar karşısında faydalı olacağını düşünüyorum”; derken diğeri (K49) "Dersin ana konusu olduğundan önemlidir diye tahmin ediyorum" şeklinde görüş bildirmiştir.

Akademik yazmayı doğru ve anlamlı bir şekilde önemli bulduklarını ifade eden katılımcıların yanında akademik yazmayı yanlış bir gerekçeyle önemli bulanlar da olmuştur. Okul öncesi öğretmenliği bölümünden 4 katılımcı akademik yazmayı resmi yazışmalarla ilişkili bularak önemli bulduğunu ifade etmiş̧; katılımcılardan birkaçı (K5) "Önemli buluyorum. Çünkü hayatımızın her aşamasında karşımıza çlkıyor. Örneğin bir devlet dairesinde veya herhangi bir kuruma yazı gönderdiğimizde bize gerekli olduğunu düşünüyorum"; (K76) "Resmi birçok kurum ve kuruluşta işime yarayacağını düşünüyorum." şeklinde görüş bildirmiştir. Öğretmen adaylarının dönem başında akademik yazmaya dair kavram yanılgıları bu soruyla belirginleşmiştir.

Akademik yazmayı önemli bulanlara karşılık İngilizce öğretmenliği bölümünden 7 katılımcı akademik yazma konusunun önemli olmadığını düşünmüş̧tür. Bu kategoride görüş bildirenler (K60) "Aslında İngilizce öğretmenliği okuyan bir öğrenci olarak pek önemli bulmuyorum çünkü biz kendimizi İngilizce yazarak geliştirebiliriz"; (K65) "Pek önemli olduğu söylenemez. Çünkü ben İngilizce öğretmenliği okuyorum. İngilizce akademik yazı yazmak benim için daha yararlı” şeklinde düşüncelerini dile getirmiştir. Eğitim fakültelerinin bütün bölümlerinde zorunlu olarak okutulan Türk Dili II dersinin ana konusuna karşı sadece İngilizce Öğretmenliği bölümünden bazı öğrencilerin bu şekilde olumsuz tavır sergilemesi, bölümlerinin yabancı dil merkezli olması ve bu dili her yönüyle öğrenme arzusuyla önceliği İngilizceye vermelerinden kaynaklanabilir. Ayrıca bazı öğrenciler, İngilizce öğretmenliği müfredatındaki Yazma Becerileri I ve II adlı dersler yoluyla akademik yazma konusuna zaten odaklandıklarını, bu sebeple Türkçe akademik yazmaya ilgilerinin az olduğunu da dile getirmişlerdir. Oysa ana dilde yazma becerisi kazanmak, İngilizce yazmaya da katkı sağlayabilir.

Okul öncesi öğretmenliği bölümünden 8 , Özel eğitim öğretmenliği bölümünden 5, İngilizce öğretmenliği bölümünden 2, Sosyal bilgiler öğretmenliği bölümünden 1 olmak üzere 16 katılımcı ise akademik yazmanın önem ve gerekliliğine dair herhangi bir görüş bildirmemiştir. Bu kategoride görüş bildirenlerin ortak yanı akademik yazma konusunda da bilgi sahibi olmadıklarını ifade etmeleridir. Katılımcllar bilgi sahibi olunmayan konunun önemi ve gerekliliği hakkında görüş belirtmemiştir.

Sonuç olarak, katılımcıların \%20,51’i akademik yazmanın önemine dair görüş bildirmezken, \%8,97’isi olumsuz görüş bildirerek Türkçe akademik yazmayı önemsememiş, \%65,38'i doğru ve anlamlı gerekçelerle akademik yazmayı önemli bulmuş, \%5,13’ü ise yanlış bir gerekçeyle önemli bulduğunu ifade etmiştir. 


\section{Araştırmanın dördüncü alt problemine ilişkin bulgular ve yorum}

Öğretmen adaylarının dönem sonunda akademik yazma konusunu önemli bulma durumlarını belirlemek amacıyla, Türk Dili II dersinin içeriği olan "Akademik yazma konusunu önemli buluyor musunuz? Gerekçelerini açıklayınız.” sorusu sorulmuştur. Bu soruya katılımcılar tarafından verilen cevaplar ve elde edilen verilerin frekans ve yüzde değerleri Tablo 5 'te verilmiştir.

\begin{tabular}{lcc}
\hline Ifadeler & $\boldsymbol{f}$ & $\mathbf{\%}$ \\
\hline Lisansüstü eğitimde yararlı olacağı için önemli bulma & 22 & 28,21 \\
Akademik açıdan yararlı olduğu için önemli bulma & 21 & 26,92 \\
Akademik dil ve yazı ile ilgili bilgi edindiği için önemli bulma & 9 & 11,54 \\
Mesleki gelişim için önemli bulma & 8 & 10,26 \\
Yazma becerisinin geliştirilmesi için önemli bulma & 5 & 6,41 \\
Fikri yok & 5 & 6,41 \\
Bireysel gelişim için önemli bulma & 3 & 3,85 \\
Dersin çok erken dönemde verildiğini düşünme & 3 & 3,85 \\
Bilimin gelişmesine katkı sağladığı için önemli bulma & 2 & 2,56 \\
\hline Toplam & 78 & 100 \\
\hline
\end{tabular}

Tablo 5: Öğretmen adaylarının dönem sonunda Türk Dili II dersinin içeriği olan akademik yazma konusunu önemli bulma durumları

Okul öncesi öğretmenliği bölümünden 4, Özel eğitim öğretmenliği bölümünden 1 katılımcı akademik yazmayı önemli bulup bulmadığına dair herhangi bir görüş bildirmemiştir. İngilizce öğretmenliği bölümünden 2, Okul öncesi öğretmenliği bölümünden 1 katılımcı ise Türk Dili II dersinin seviyelerinin çok üzerinde olduğunu belirterek bunun çok erken bir dönemde verildiğini son sinıfta verilmesinin daha yararlı olacağını belirtmiştir. Buna karşılık sırasıyla Okul öncesi öğretmenliği bölümünden 26, Özel eğitim öğretmenliği bölümünden 25, İngilizce öğretmenliği bölümünden 15, Sosyal bilgiler öğretmenliği bölümünden 4 olmak üzere toplam 70 katılımcı akademik yazmayı çeşitli açılardan önemli bulduklarını ifade etmişlerdir. 22 katılımcı akademik yazmayı "lisansüstü eğitimde yararlı olması” yönünden önemli bulmuştur: (K41) “Önemli çünkü yüksek lisans ve doktora yapmak isteyenler bu yazı türünde çalışmalar yapar”; (K64) "Önemli buluyorum çünkü yüksek lisans yapmak istiyorum o zaman fazlasıyla işime yarayacak” demiştir. 21 katılımcı akademik açıdan yararlı olmasından dolayı önemli bulduğunu belirtmiştir. (K10) "Akademik yazma dersini önemli buluyorum. Çünkü ileride kullanabileceğim bilgileri öğreniyorum. Tez ve makalenin nasıl yazıldığını bilmek bana kolaylık sağlayacaktır. Sadece yazma için değil, okuduğum makaleleri daha iyi anlarım. Bunların hangi aşamalardan geçtiğini kolaylıkla değerlendirebilirim.” ifadelerini kullanarak görüşlerini belirtmişlerdir. Katılımcıların 9'u "akademik dil ve yazı ile ilgili bilgi sahibi olma" açısından önemli bulduğunu belirtmiştir: (K48) "Önemli buluyorum çünkü bu derste bilimsel araştırma yapmayı, incelemeyi ve bilimsel yazı nasıl yazılır bilgi sahibi olduk"; (K77) "Akademik yazı yazma, eğitim hayatımızda yazacağımız yazılar açısından çok önemlidir. Ödev hazırlarken veya makale yazarken nasıl bir dil kullanacağımızı öğrendik" demiştir. Katılımcıların 8“i akademik yazma konusunu "mesleki gelişim” açısından önemli bulmuştur: (K6) "Önemli buluyorum öğretmen olduğumuzda bize faydalı olacak"; (K54) "Evet buluyorum. Çünkü öğretmen olacağız. Meslek hayatımızda mutlaka karşımıza çlkacak” ifadelerini kullanarak akademik yazma konusunun önemini açıklamışlardır. Katılımcıların 5 ’i "yazma becerisini geliştirmesi” açısından akademik yazmayı önemli bulduğunu belirtmiştir: (K44)

\footnotetext{
Adres $\mid$ Address

İstanbul Medeniyet Üniversitesi, Eğitim Bilimleri Fakültesi, Türkçe İstanbul Medeniyet University, Faculty of Education Sciences, ve Sosyal Bilimler Eğitimi Bölümü, Türkçe Eğitimi ABD Cevizli Turkish and Social Scinces Education, Turkish Language Teaching Kampüsü, Kartal-İstanbul/TÜRKIYE $\quad$ Education, Cevizli Campus, Kartal-İstanbul /TURKEY e-posta: editor@rumelide.com 1 e-mail: editor@rumelide.com
} 
"Önemli buluyorum çünkü daha sistemli ve anlaşılır bir şekilde yazı yazmamız için gerekli bir ders" demiştir. 3 katılımcı bireysel gelişim için, 2 katılımcı bilim alanının gelişmesine katkıda bulunduğu için önemli bulduğunu söylemiştir.

İngilizce öğretmenliği bölümü öğrencilerinin son görüşmede akademik yazmanın önemine dair görüşlerini değiştirdikleri tespit edilmiştir. Özellikle (K25) “Açıkçası önemli bulmuyordum fakat şu an gayet önemli olduğunu düşünüyorum. Gerekçesi ise araştırılmaya değer düşünce ve konu bilim alanının gelişmesine katkıda bulunur."; (K33) "Yararlıdır tabii ki, sonuçta bilimsel düşünceyi geliştiriyor.”; (K76) "İlk başta bulmuyordum fakat dersi gördükçe bilmediğim ve oldukça önemli konular barındırdığını öğrendim.” şeklindeki ifadeler ders sürecinin katılımcıları olumlu yönde etkilediğini göstermiştir.

Sonuç olarak, akademik yazmanın önemine ilişkin katılımclların \%6,41’i görüş bildirmezken \%89,75’i akademik yazmayı bilimsel, akademik, lisansüstü, mesleki ve bireysel açılardan önemli bulduklarını \%3,85\% ise dersin çok erken bir dönemde verildiğini ifade etmiştir. Bu da göstermektedir ki öğrencilerin dönem sonunda dersi önemli bulma durumları dönemin başında yapılan ön görüşmeye göre oldukça değişmiş, çoğunluk dersin temel içeriği olan akademik yazma konusunun önemli olduğunu anlamıştır.

\section{Araştırmanın beşinci alt problemine ilişkin bulgular ve yorum}

Dönem sonunda öğretmen adaylarının akademik yazma konusunda kendini yeterli bulma durumlarını belirlemek amacıyla "Kendinizi akademik yazma konusunda yeterli buluyor musunuz? Cevabınız hayır ise sebebini yazınız." sorusu sorulmuştur. Bu soruya katılımcılar tarafından verilen cevaplar ve elde edilen verilerin frekans ve yüzde değerleri Tablo 6’ da verilmiştir.

\begin{tabular}{llc}
\hline İfadeler & $\boldsymbol{f}$ & $\mathbf{\%}$ \\
\hline Bilgi birikimi ve donanımı az olduğu için yetersiz bulma & 32 & 41,03 \\
Kendini yeterli bulma & 18 & 23,08 \\
Kısmen yeterli bulma & 12 & 15,38 \\
Sadece teorik bilgisi olduğu, deneyimi az olduğu için yetersiz bulma & 9 & 11,54 \\
Derse ilgisi olmadığı için yetersiz bulma & 3 & 3,85 \\
Önceki lisans programındaki deneyiminden dolayı yeterli bulma & 2 & 2,56 \\
Fikri yok & 2 & 2,56 \\
\hline Toplam & 78 & 100 \\
\hline
\end{tabular}

Tablo 6: Öğretmen adaylarının akademik yazma konusunda kendini yeterli bulma durumları

Özel eğitim öğretmenliği bölümünden 6, Okul öncesi öğretmenliği bölümünden 6, İngilizce öğretmenli bölümünden 5, Sosyal bilgiler öğretmenliği bölümünden 1 olmak üzere toplam 18 katılımcı akademik yazma konusunda kendini yeterli bulduğunu belirtmiştir. Okul öncesi öğretmenliği bölümünden 6 , Özel eğitim öğretmenliği bölümünden 4, İngilizce öğretmenliği bölümünden 2 olmak üzere toplam 12 katılımcı kendisini kısmen yeterli bulduğunu ifade etmiştir. Özel eğitim öğretmenliğinden 2 katılımcı ise önceki lisans programındaki deneyiminden dolayı kendini yeterli bulduğunu belirtmiştir. Daha önce bir lisans programından mezun olan öğrenciler, dersi yeni alan öğrencilere göre kendilerini konulara daha yakın bulmuşlardır. Okul öncesi öğretmenliğinden 2 katılımcı ise herhangi bir görüş bildirmemiştir.

\footnotetext{
Adres $\mid$ Address

İstanbul Medeniyet Üniversitesi, Eğitim Bilimleri Fakültesi, Türkçe İstanbul Medeniyet University, Faculty of Education Sciences, ve Sosyal Bilimler Eğitimi Bölümü, Türkce Eğitimi ABD Cevizli Turkish and Social Scinces Education, Turkish Language Teaching Kampüsü, Kartal-İstanbul/TÜRKIYE $\quad$ Education, Cevizli Campus, Kartal-İstanbul /TURKEY e-posta: editor@rumelide.com 1 e-mail: editor@rumelide.com
} 
Yeterlik kazandığını düşünen ve görüş belirtmeyenlere karşılık Okul öncesi öğretmenliği bölümünden 17, Özel eğitim öğretmenliği bölümünden 14, İngilizce öğretmenliği bölümünden 10, Sosyal bilgiler öğretmenliği bölümünden 3 olmak üzere toplam 44 katılımcı akademik yazma konusunda bilgi birikimi ve donanım azlığı, teorik bilgiye karşılık deneyim azlığı, derse ilgisizlik yönünden kendisini yetersiz bulduğunu belirtmiştir. Bilgi birikimi ve donanımı az olduğu için kendini yetersiz bulanlardan bazıları (K21) "Yeterli bulmuyorum, çünkü bu yıl ilk kez karşılaştığım bir kavram ve akademik yazı hakkında çok fazla araştırma yapmadım”; (K42) "Kendimi yeterli bulmuyorum. Çünkü; bu konuda tecrübelerimin az olduğunu düşünüyorum. Bunun için kendimi geliştirmem gerekiyor” şeklinde görüş belirtmiştir. Teorik bilgisine karşılık deneyimi az olduğu için kendisini yetersiz bulanlardan bazıları ise (K13) "Yeterli bulmuyorum. Çünkü bu dönem akademik yazı nasıl yazılır öğrendim ama daha hiç yazmadığım için yetersizim"; (K59) "Teorik bilgi olarak yeterli buluyorum ancak yazıya aktarma konusunda tam olarak iyi değilim” şeklinde görüşlerini dile getirmişlerdir. Okul öncesi öğretmenliği bölümünden 3 katılımcı derse ilgisi olmadığı için kendisini yetersiz bulmuştur. Dolayısıyla katılımcıların \%56,42'si yani çoğunluğu akademik yazma konusunda kendisini yetersiz bulmakta, \%41,02'si yeterli bulmakta, \%2,56sı ise nötr kalmaktadır.

Kendisini yetersiz bulan öğrencilerin cevaplarından akademik yazmayı sadece bilimsel makale ve araştırma raporu gibi büyük yazı türleri yazma şeklinde algıladıkları anlaşılmıştır. Bu sebeple sıkça akademik yazmanın yeterli seviyede alan bilgisine sahip olunca başlayacağını düşünmüşlerdir. Oysa akademik yazma açıklayıcı, tartışmacı paragraflardan klasik sınav sorularının cevaplarından bilimsel makale ve teze kadar geniş bir yelpazede karşımıza çıkar. Öğretmen adayları küçük yazı çalışmalarında da kendilerine güvenemediklerini, bir türlü ilk cümleye başlayamadıklarını, yazma faaliyetlerinin seviyelerinin üzerinde olduğunu ifade ederek de bu alanda zorluklar yaşadıklarını göstermişlerdir. Bu süreçte bilgi birikimi sağlayacak, sözcük dağarcığını güçlendirecek, Türkçenin doğru ve etkili şekilde kullanılmasını sağlayacak düzeyde makale, dergi, kitap okumanın önemi öğrenciye aşılanmaya çalışılmıştır.

\section{Araştırmanın altıncı alt problemine ilişkin bulgular ve yorum}

Dersin kazanımlarının neler olduğunu belirlemek amacıyla öğretmen adaylarına "Akademik yazma dersinin size kazandırdıkları nelerdir?” sorusu sorulmuştur. Bu soruya katılımcılar tarafından verilen cevaplar ve elde edilen verilerin frekans ve yüzde değerleri Tablo 7'de verilmiştir.

\begin{tabular}{|c|c|c|c|}
\hline \multicolumn{2}{|l|}{ İfadeler } & $\mathbf{f}$ & $\%$ \\
\hline \multicolumn{2}{|l|}{ Araştırma raporunun yazımı ile ilgili bilgi edinme } & 30 & 38,46 \\
\hline \multicolumn{2}{|l|}{ Akademik yazı türlerini öğrenme } & 10 & 12,82 \\
\hline \multicolumn{2}{|c|}{$\begin{array}{l}\text { Bilimsel araştırma süreci ve araştırma raporunun yazımı ile ilgili bilgi } \\
\text { edinme }\end{array}$} & 9 & 11,54 \\
\hline \multicolumn{2}{|l|}{ Yazma becerisini geliştirme } & 7 & 8,97 \\
\hline \multicolumn{2}{|l|}{ Bilimsel araştırma süreci ve akademik yazı türlerini öğrenme } & 4 & 5,13 \\
\hline \multicolumn{2}{|l|}{ Araştırma raporunun özelliklerini ve bölümlerini öğrenme } & 4 & 5,13 \\
\hline \multicolumn{2}{|l|}{ Fikri yok } & 4 & 5,13 \\
\hline \multicolumn{2}{|l|}{ Tartışmacı anlatımla ilgili bilgi edinme } & 2 & 2,56 \\
\hline \multicolumn{2}{|l|}{ Etik ilkeleri öğrenme } & 2 & 2,56 \\
\hline \multicolumn{2}{|l|}{ Akademik yazmanın ciddi bir uğraş olduğunu anlama } & 2 & 2,56 \\
\hline $\begin{array}{r}\text { Adres } \\
\text { İstanbul Medeniyet Üniversitesi, Eğitim Bilimleri Fakültesi, Türkçe } \\
\text { ve Sosyal Bilimler Eğitimi Bölümü, Türkçe Eğitimi ABD Cevizli } \\
\text { Kampüsü, Kartal-İstanbul/TÜRKiYE } \\
\text { e-posta: editor@rumelide.com }\end{array}$ & \multicolumn{3}{|c|}{$\begin{array}{l}\text { Address } \\
\text { İstanbul Medeniyet University, Faculty of Education Sciences, } \\
\text { Turkish and Social Scinces Education, Turkish Language Teaching } \\
\text { Education, Cevizli Campus, Kartal-İstanbul /TURKEY } \\
\text { e-mail: editor@rumelide.com }\end{array}$} \\
\hline
\end{tabular}




\begin{tabular}{lll} 
Özet çıkarma ve anlatım biçimlerini öğrenme & 1 & 1,28 \\
Başlık oluşturma ve anlatım biçimlerini öğrenme & 1 & 1,28 \\
Araştırma raporu ile ilgili bilgi edinme ve özet çıkarmayı öğrenme & 1 & 1,28 \\
Bilimsel araştırma süreci ve tartışmacı anlatımla ilgili bilgi edinme & 1 & 1,28 \\
\hline Toplam & 78 & 100
\end{tabular}

Tablo 7: Türk Dili II dersinin içeriği olan akademik yazma eğitiminin öğretmen adaylarına kazandırdıkları

Okul öncesi öğretmenliği bölümünden 4 katılımcı $(\% 5,13)$ dersin kazanımları konusunda herhangi bir görüss bildirmezken aynı bölümden 27, Özel eğitim öğretmenliği bölümünden 26, İngilizce öğretmenliği bölümünden 17 , Sosyal bilgiler öğretmenliği bölümünden 4 olmak üzere toplam 74 katılımcı araştırma raporunun yazımı, akademik yazı türleri, bilimsel araştırma süreci, tartışmacı metin, etik ilkeler, anlatım biçimleri, özetleme, başlık oluşturma gibi konuları öğrendiklerini ifade etmişlerdir. 30 katılımcı araştırma raporunun yazımı ile ilgili bilgi edindiğini ifade etmiştir. (K16) "Bu derste üst düzey olmasa da makale yazısı nasıl yazılır, bir tez nasıl yazılır konularında bilgi sahibi oldum"; (K55) "Tez yazımı makale, başlık nasıl bulunur, bunları kazandırdı", 10 katılımcı akademik yazı türlerini öğrenme kategorisinde görüş belirtmiştir. (K30) "Makale, tez, bildiri gibi türleri öğrendim” şeklinde görüş belirtmiştir. 9 katılımcı bilimsel araştırma süreci ve araştırma raporunun yazımı ile ilgili bilgi edindiğini söylemiştir: (K28) "Akademik yazma ve araştırma konusunda yeterli bilgi elde etme yolunda olumlu etkileri olmuştur” demiştir. 4 katılımcı bilimsel araştırma süreci ve akademik yazı türlerini öğrenme kategorisinde görüş belirtmiştir. (K15) "Akademik yazı türlerinde bilgi sahibi olmak, bilimsel araştırmaların hangi basamaklardan oluştuğunu öğrenme konusunda katkı sağladı" ifadesiyle açıklamıştır. 4 katılımcı araştırma raporunun özelliklerini ve bölümlerini belirleme kategorisinde görüş belirtmiştir. (K21) "Akademik yazı yazmanın kriterlerini, nerede nasıl yazacağımızı, akademik yazı niçin yazılı, önemi nedir? vb. konularda fikir sahibi oldum” şeklinde görüş belirtmiştir. 7 katılımcı yazma becerisini geliştirdiği yönünde bilgi vermiş;; (K9) "Türk Dili 2 dersi bana, dikkatli ve düzgün şekilde yazma ve yazım kurallarına dikkat etme konusunda katkı sağlamıştır” şeklinde görüş belirtmiştir. 2 katılımcı tartışmacı anlatımla ilgili bilgi edindiğini, 2 katılımcı etik ilkeleri öğrendiğini, 2 katılımcı akademik yazının ciddi bir uğraş olduğunu anladığını, 1 katılımcı özet çıkarmayı ve anlatım biçimlerini öğrendiğini, 1 katılımcı başlık oluşturmayı ve anlatım biçimlerini öğrendiğini, 1 katılımcı araştırma raporu ile ilgili bilgi edindiğini ve özet çıkarmayı öğrendiğini, 1 katılımcı ise bilimsel araştırma süreci ve tartışmacı anlatımla ilgili bilgi edindiğini ifade etmiştir.

Tablo 7'den katılımcıların \%94,87'sinin akademik yazma eğitiminden olumlu derecede yararlandıkları rahatlıkla görülebilir. Ancak kategori ve frekanslar incelendiğinde hem teorik hem pratik düzeydeki öğrenmeler arasında büyük bir fark olduğu anlaşılmaktadır. Katılımcıların \%75,64'ü akademik yazı türleri ve özellikleri, bilimsel araştırma süreci, araştırma raporu ve etik ilkeler hakkında teorik düzeyde bilgi edinmiş, buna karşılık sadece \%7,68’i başlık yazma, özet çıarma, tartışmacı metin yazma ve yazma becerisini geliştirme kategorilerinde görüş bildirerek öğretilenlerin pratiğe aktarılması ve beceri kazanılması noktasında eksikler olduğunu göstermişlerdir.

\section{Araştırmanın yedinci alt problemine ilişkin bulgular ve yorum}

Öğretmen adaylarının dönem boyunca derste yapılan etkinliklere ilişkin görüşlerini belirlemek amacıyla dönemin sonunda "Derste yapılan etkinlikler hakkında görüşleriniz nelerdir?" sorusu sorulmuştur. Bu soruya katılımcılar tarafından verilen cevaplar ve elde edilen verilerin frekans ve yüzde değerleri Tablo 8' de verilmiştir. 


\begin{tabular}{lll}
\hline İfadeler & $\boldsymbol{f}$ & $\mathbf{\%}$ \\
\hline Yazma becerisini geliştirdiği için önemli bulma & 23 & 29,49 \\
Öğrenmeyi pekiştirdiği için önemli bulma & 22 & 28,21 \\
Etkinliklerin yetersiz olduğunu düşünme & 7 & 8,97 \\
Tartışmacı metin yazmayı öğrendiği için önemli bulma & 6 & 7,69 \\
Yazma cesareti edindiği için önemli bulma & 3 & 3,85 \\
Etkinlikleri ağır bulma & 3 & 3,85 \\
Derse ilgiyi arttırdığı için önemli bulma & 3 & 3,85 \\
Düşünme becerisini geliştirdiği için önemli bulma & 2 & 2,56 \\
Etkinlikleri kısmen yeterli bulma & 2 & 2,56 \\
Pratik ve etkili olduğunu düşünme & 1 & 1,28 \\
Dersi eğlenceli hale getirdiğini düşünme & 1 & 1,28 \\
Aktif öğrenmeye katkıda bulunma & 1 & 1,28 \\
Yazma becerisini geliştirme ve öğrenmeyi pekiştirme & 1 & 1,28 \\
Yazarak kendini daha iyi ifade ettiğini düşünme & 1 & 1,28 \\
Etkinlikleri yeterli bulma & 1 & 1,28 \\
Fikri yok & 1 & 1,28 \\
\hline Toplam & 78 & 100 \\
\hline
\end{tabular}

Tablo 8: Öğretmen adaylarının Türk Dili II dersinde yapılan akademik yazma ile ilgili etkinliklere yönelik görüşleri

Dönem boyunca yazma etkinliklerinde akademik dilin kullanımı ve akademik yazılarda dil düzeyine dikkat çekilerek bu dile ulaşılmasını sağlayacak düşünsel yazılar üzerinde durulmuştur. Akademik yazıların türsel özelliklerini kavratmak için alanlarıyla ilgili bilimsel metinlerle (makale ve tezler) tanıştırılmış, ilgi duydukları konuları belirlemeleri ve bu konularda yazılmış makaleleri okumaları istenmiş, sonrasında seçtikleri makalelerin biçim ve içerik özelliklerini inceleyen, değerlendiren sorular yöneltilmiş, bu soruların cevaplarını veren makale inceleme yazıları yazdırılmıştır. Buna ek olarak birkaç defa uzun bir metni belli oranda küçülterek özet çıkarma ve belli zaman aralıklarıyla tartışmacı metin oluşturma gibi uygulamalarla yazma becerisi kazandırılmaya çalışılmıştır.

Öğretmen adaylarına yöneltilen “Derste yapılan etkinlikler hakkında görüşleriniz nelerdir?” sorusuna cevapları genellikle olumlu yönde şekillenmiş, Okul öncesi öğretmenliği bölümünden 26, Özel eğitim öğretmenliği bölümünden 23, İngilizce öğretmenliği bölümünden 14, Sosyal bilgiler öğretmenliği bölümünden 2 olmak üzere toplam 65 katılımcı etkinlikleri yazma becerisini geliştirme, öğrenmeyi pekiştirme, tartışmacı metin yazmayı öğrenme, yazma cesareti edinme, derse ilgiyi artırma, düşünme becerisi geliştirme, pratik ve etkililik vb. gerekçelerle önemli bulduğunu ifade etmiştir.

Etkinliklerin yazma becerisini geliştirdiğini ifade eden 23 katılımcıdan birkaçı (K23) "Yazı yazma yeteneği pek olmayan biri olduğum için, bu derste yaptığımız etkinlikler sonucu biraz daha çaba göstersem daha iyi yapacağımı düşündürdü"; (K27) "Derslerde birçok yazma etkinlikleri yaptık. Makale incelemesi, özetleme teknikleri, bir konu üzerinde tartışmacı metin yazma gibi. Bu etkinlikler bizler için oldukça verimliydi. Konuları anlatılıp geçilmedi, anlatılanlar uygulandı.” şeklinde görüş belirtmiştir. Yapılan etkinliklerin öğrenmeyi pekiştirdiğini düşünen 22 katılımcıdan birkaçı (K44) "Derslerde yapılan etkinliklerde kendimizi geliştirmiş ve teorik anlamda öğrendiğimiz bilgileri pekiştirmiş olduk"; (K72) "Yaptığımız etkinliklerle öğrendiklerimiz kalıcı oldu" demiştir. 6 katılımcı 
Tartışmacı metin yazmayı öğrendiği için etkinlikleri önemli bulan 6 katılımcıdan biri (K9) "Tartışmacı metnini çok faydalı buldum, bunun yazımını da ders sayesinde gayet iyi öğrendiğimi düşünüyorum” şeklinde görüş belirtmiştir. Yazma cesareti edindiği için etkinlikleri önemli bulan 3 katılımcıdan biri (K23) "Yazı yazma yeteneği pek olmayan biri olduğum için bu derslerde yaptığım etkinlikler sonucu artık bir konuda araştırma yapıp yazabileceğimi düşünüyorum” ifadesiyle görüşünü belirtmiştir. Derse ilgiyi arttırması nedeniyle etkinlikleri önemli bulan 3 katılımcıdan biri (K33) "Yapılan etkinlikler derse daha iyi adapte olmamızı sağlıyor ve derslere daha istekli geliyoruz” demiştir. 2 katılımcı düşünme becerisini geliştirdiği, 1 katılımcı pratik ve etkili olduğu, 1 katılımcı dersi eğlenceli hale getirdiği, 1 katılımcı aktif öğrenmeye katkıda bulunduğu, 1 katılımcı yazma becerisini geliştirdiği ve öğrenmeyi pekiştirdiği, 1 katılımcı yazarak kendini daha iyi ifade ettiği için önemli bulduğunu belirtmiştir. 1 katılımcı ise etkinlikleri gerekçe göstermeksizin sadece yeterli gördüğünü ifade etmiştir.

Olumlu görüş bildiren \%83,34'e karşllık katılımcıların \%15,38’i etkinliklerin yetersiz ve ağır olduğunu, kısmen yeterli olduğunu belirtmiştir. Okul öncesi öğretmenliği ve Sosyal bilgiler öğretmenliği bölümünden 2 katılımcı gerekçe bildirmeden etkinlikleri kısmen yeterli bulduğunu ifade etmiştir. Özel eğitim öğretmenliği bölümünde 3, İngilizce öğretmenliği bölümünden 3 , Okul öncesi öğretmenliği bölümünden 1 olmak üzere olmak üzere toplam 7 katılımcı ise etkinliklerin yetersiz olduğu yönünde görüş bildirmiştir. (K12) "Derslerde yapılan etkinlikleri yeterli görmüyorum”; (K20) "Derslerde yapılan yazma etkinlikleri yazma gücümüzü geliştirir. Ama derste yapılan etkinlikleri yeterli bulmadım. Daha çok etkinlik yapılsaydı belki daha iyi yazabilirdik.” demiştir. Özel eğitim öğretmenliği öğrencilerinin derse ilgi ve katılımı yüksek olmakla birlikte daha fazla etkinlik yapılmasının gerekliliğini derslerde ifade etmişlerdir. İngilizce öğretmenliği bölümü öğrencilerinden bazıları Türkçe yerine İngilizce yazma becerilerinin geliştirilmesi gerektiğini düşünse de yazma etkinliklerinin kendilerini geliştirdiğini belirtip bunun çoğaltılması gerektiğini dile getirmişlerdir. Katılımcıların bu yöndeki eleştirileri haklı olmakla birlikte şubelerin mevcudunun kalabalık oluşu ve öğretim elemanının iş yükünün çokluğu etkinliklerin niceliğini etkilemiştir.

Okul öncesi öğretmenliği bölümünden 1 katılımcı etkinliklerin önem ve yeterliliğine dair görüş bildirmezken aynı bölümden 2, Sosyal bilgiler öğretmenliği bölümünden 1 olmak üzere 3 katılımcı etkinliklerin, seviyelerinin üzerinde ağır olduğunu belirtmiştir. (K42) "Etkinlikler bizim ilgi eksikliğimizde ve işlediğimiz diğer derslerdeki etkinliklere göre zordu” demiştir. $\mathrm{Bu}$ ifadeden anlaşllıyor ki Türk Dili ile diğer derslerdeki etkinliklerin düzeyinde bir fark var. Bu durum akademik yazmanın üst düzey bir faaliyet olması ile alakalı olabilir. Bunun yanında öğrencilerin dil becerilerinin özellikle yazma becerisinin önceki kademelerde yeterince gelişmemiş olması da bu güçlüğü açıklayabilir. $\mathrm{Bu}$ sorun bir taraftan dersin içeriğine uygun ders kitaplarının yazılmamış olması nedeniyle öğrencilerin seviyelerine uygun örnek metinlere ve etkinliklere kolaylıkla ulaşılamaması bir taraftan da farklı bölümlerin bir arada bu dersi alması nedeniyle öğrencilerin bütününün ilgisini çekecek nitelikte etkinlikler yapılamamasından kaynaklanmıştır.

\section{Araştırmanın sekizinci alt problemine ilişkin bulgular ve yorum}

Tartışmacı metin yazma etkinliği bu dersin öğrenci üzerindeki etkilerini, konuları öğrenme durumlarını anlamak için önemli bir yol olarak seçilmiştir. Öğrencilerden ilk derste "Bir kitabı okumak mı uyarlama filmini seyretmek mi istersiniz?” sorusu sorularak konuyla ilgili bir tartışma metni yazmaları istenmiştir. Dönem boyunca teorik ve uygulamalı düzeyde sürdürülen akademik yazma eğitiminin sonunda öğrencilere aynı konu tekrar verilerek dönem boyunca öğretilenleri dikkate alarak bir tartışmacı metin yazmaları istenmiştir. Bu konu ödev olarak verilmemiş, son derste 80 dakikalık

Adres

İstanbul Medeniyet Üniversitesi, Eğitim Bilimleri Fakültesi, Türkçe ve Sosyal Bilimler Eğitimi Bölümü, Türkçe Eğitimi ABD Cevizli Kampüsü, Kartal-İstanbul/TÜRKIYE e-posta: editor@rumelide.com
Address

Istanbul Medeniyet University, Faculty of Education Sciences,

Turkish and Social Scinces Education, Turkish Language Teaching

Education, Cevizli Campus, Kartal-İstanbul /TURKEY

e-mail: editor@rumelide.com 
bir sürede konuyla ilgili iddia, karşı iddia gibi temel unsurların yazılı ifadesi, gerekçe ve kanıtların sunularak iddianın kanıtlanması beklenmiştir.

Öğretmen adaylarının dönemin başında ve sonunda yazdıkları tartışmacı metinlerde bilgi ve becerilerini aktarım durumları Tablo 9' da verilmiştir.

\begin{tabular}{|c|c|c|c|c|}
\hline \multirow{2}{*}{ Değerlendirme kriterleri } & \multicolumn{2}{|c|}{$\begin{array}{l}\text { Dönem başı } \\
\text { değerlendirme }\end{array}$} & \multicolumn{2}{|c|}{$\begin{array}{l}\text { Dönem sonu } \\
\text { değerlendirme }\end{array}$} \\
\hline & $f$ & $\%$ & $f$ & $\%$ \\
\hline Başlık yazma & 12 & 15,38 & 70 & 89,74 \\
\hline Giriş-Gelişme-Sonuç bölümlerini oluşturma & 27 & 34,61 & 57 & 55,87 \\
\hline Akademik dilin kullanımı & 18 & 23,08 & 32 & 41,02 \\
\hline Anlatım bozukluğu yapmadan yazma & 20 & 25,64 & 20 & 25,64 \\
\hline Yazım kurallarına uyma & 16 & 20,51 & 16 & 20,51 \\
\hline Geçiş ve bağlantı ifadelerini kullanma & 49 & 62,82 & 60 & 76,92 \\
\hline Düşünceyi geliştirme yollarını kullanma & 23 & 29,48 & 41 & 52,56 \\
\hline İddia cümlesini anlaşılır bir şekilde yazma & 27 & 34,61 & 45 & 57,69 \\
\hline İddiayı kanıtlayabilme & 2 & 2,56 & 10 & 12,82 \\
\hline
\end{tabular}

Tablo 9: Öğretmen adaylarının dönem başında ve sonunda tartışmacı metin yazma etkinliğinde öğrendikleri bilgi ve becerileri aktarım durumları

Öğrencilerin tartışmacı metin oluşturmada bilgi ve beceri kazanıp kazanmadığını anlamak için Tablo 9'daki ölçme değerlendirme tablosu oluşturulmuştur. Dönemin başında ve sonunda yapılan tartışmacı metin etkinliği kapsamında öğrencilerin yazıları (78 kişi); başlık oluşturma giriş-gelişme-sonuç bölümlerini planlı şekilde oluşturma, dilin kullanımı, anlatım ve yazım kurallarına riayet etme, cümleler ve paragraflar arasında geçiş ve bağlantı ifadeleri kullanma, düşünceyi geliştirme yollarından faydalanma, iddia cümlesini anlaşılır şekilde yazma, iddiayı kanıtlama gibi kriterlere uygunluğu açısından incelenmiştir.

İlk yazıda başlık oluşturma oranı \%15,38 iken dönem sonunda bu \%89,74'e yükselmiştir. Girişgelişme-sonuç bölümlerini planlı şekilde oluşturma oranı başta \%34,61 iken son yazıda bu \%55,87ye yükselmiştir. Öğrenciler, ilgi çekici başlıklar oluşturmaya gayret etmişler, yazılarını giriş, gelişme ve sonuç bölümü içerecek şekilde düzenlemişler ve bu noktada belli ölçüde başarılı olmuşlardır.

Açık, basit, etkin, dolaysız bir anlatımla, bilimsel bir dil ve üslupla konuya uygun üst düzey sözcükleri seçerek, terimlere ve tanımlara yer vererek yazma şeklinde açıklanan akademik dilin kullanımında ilk yazıda başarı gösterme oranı \%23,08 iken son yazıda bu \%41,02’ye yükselmiştir. Anlatım bozukluğu yapmadan yazma ve imla kurallarına uyma durumları yine ayrıca değerlendirilmiştir. Buna göre öğrencilerin hemen hemen hepsi anlatım bozukluğu ve yazım yanlışı yapmadan yazma noktasında bir değişiklik yani düzelme gösterememiştir. İlk ve son yazıda anlatım bozukluğu yapmadan yazma oranı \%25,64 olarak tespit edilmiştir. Yazım kurallarına uyan öğrenci sayısında da anlamlı bir değişiklik olmamış, ilk ve son yazıda yazım kurallarını ve noktalama işaretlerini doğru kullanma oranı \%20,51 olarak belirlenmiştir. Dolayısıyla öğrencilerin Türkçeyi doğru kullanmada zayıf oldukları, yazı diline hâkim olamadıkları, dolayısıyla yazma becerisinin tam olarak gelişmediği ortaya çıkmıştır.

\footnotetext{
Adres $\mid$ Address

İstanbul Medeniyet Üniversitesi, Eğitim Bilimleri Fakültesi, Türkçe İstanbul Medeniyet University, Faculty of Education Sciences, ve Sosyal Bilimler Eğitimi Bölümü, Türkce Eğitimi ABD Cevizli Turkish and Social Scinces Education, Turkish Language Teaching Kampüsü, Kartal-İstanbul/TÜRKIYE $\quad$ Education, Cevizli Campus, Kartal-İstanbul /TURKEY e-posta: editor@rumelide.com 1 e-mail: editor@rumelide.com
} 
Cümle ve paragraflarda geçiş ve bağlantı ifadelerini kullanarak düşüncenin akışını düzenleme oranı ilk yazıda \%62,82 iken son yazıda bu \%76,92'ye yükselmiştir. Düşünceyi geliştirme yollarından faydalanma oranı ilk yazıda \%29,48 iken son yazıda bu \%52,56\%ya yükselmiş, öğrencilerin çoğunlukla örneklendirme yolunu seçtikleri; karşılaştırmada zayıf oldukları; tanımlama, alıntı yapma, sayısal verilerden yararlanma gibi yolları kullanmadıkları görülmüştür. İddia cümlesini anlaşılır şekilde yazma oranı ilk yazıda \%34,61 iken son yazıda bu \%57,69'a yükselmiştir. Son olarak iddianın gerekçeleriyle birlikte kanıtlanması noktasında başarı gösterme oranı ilk yazıda \%2,56 iken son yazıda bu oran \%12,82'ye yükselmiştir.

\section{Tartışma, sonuç ve öneriler}

Öğretmen adaylarının Türk Dili II dersi üzerinden akademik yazma eğitimine yönelik görüşlerinin incelendiği bu çalışmada, ön görüşmede katılımcıların sadece \%20,51’i akademik yazma kavramının tanımını yapabilirken büyük çoğunluğunun bu kavramı tanımlayamadığı ve akademik yazmayı resmi yazışmalarla karıştırdığı ortaya çıkmıştır. Son görüşmede katılımcıların \%93,59'unun akademik yazmayı "bilimsel araştırma sürecinin yazıya aktarılması, bilimsel bir üslupla yazma, objektif ve kanıtlanabilir yazı, bilimsel yazı" şeklinde tanımladı̆̆ı, kavram yanılgılarının da azaldığı anlaşılmıştır. Bu bağlamda Türk Dili II dersinin, akademik yazma konusunda öğrencilere katkı sağladığı söylenebilir.

Akademik yazmanın önemine dair ön görüşmede katılımclların \%20,51’i görüş bildirmezken, \%8,97'si olumsuz görüş bildirmiş, \%5,13’ü kavram yanılgısı doğrultusunda akademik yazmayı resmi yazışmalarda beceri kazanacaklarını düşünerek önemli bulmuş, \%65,38'i ise eğitim hayatına, meslek hayatına ve lisansüstü eğitime katkı sağlayacağı düşüncesiyle önemli bulduğunu belirtmiştir. Olumsuz görüş bildirenlerin tümünün İngilizce öğretmenliği bölümünden olması dikkat çekmiştir. Katılımcıların bu yöndeki olumsuz görüşlerinin sebebi, alanlarının yabancı dil olmasıyla İngilizceye ağırlık vermeleri, zaten güz ve bahar dönemlerinde akademik yazmayla ilgili Yazma Becerileri adlı alan dersini almalarıdır. Son görüşmede İngilizce öğretmenliği bölümünden gelen olumsuz görüşlerin azaldığı, ders sürecinin onları olumlu yönde etkilediği anlaşılmıştır. Dönemin sonunda katılımcıların \%89,75’i dolayısıyla tüm bölümlerden çoğunluğun akademik yazmayı bilimsel gelişme, akademik kariyer, mesleki ve bireysel gelişim açısından faydalı ve kıymetli bulduklarını ifade etmeleri, öğretmen adaylarının Türk Dili II dersinin ana içeriği olan akademik yazma eğitiminin önem ve gerekliliğini kavradıklarını göstermiştir.

Dönem sonunda öğretmen adaylarının akademik yazma konusunda kendilerini yeterli bulanlarla kısmen yeterli bulanların oranı \%41,02 iken kendilerini yetersiz görenlerin oranı \%56,42 olarak belirlenmiştir. En çok Okul öncesi öğretmenliği bölümünden olmak üzere sırassyla Özel eğitim öğretmenliği, İngilizce öğretmenliği ve Sosyal bilgiler öğretmenliği bölümlerinden katılımcllar bilgi birikimi ve donanımın az olması, sadece teorik bilgisi olup deneyiminin az olması ve ilgisizlik gibi nedenlerle akademik yazmada kendilerini yetersiz bulduklarını ifade etmişler, akademik yazmayı sadece bilimsel makale ve araştırma raporu yazma faaliyeti olarak algılayıp alanlarında uzmanlaşınca akademik yazmada yeterlik kazanacaklarını düşünmüşler, etkinlikler esnasında da zorlandıklarını, yetersiz hissettiklerini ifade etmişlerdir. Türkçe öğretmenliği öğrencilerinin yazılı anlatım derslerine yönelik tutumlarını inceleyen Bağcı da (2007) çalışmasında öğretmen adaylarının yazma becerisi kazanmanın önemini kavradıklarını ancak yazılı anlatımdaki yetersizliklerinden yakındıklarını, sıkıntı çektiklerini belirtmiştir. Çalışmamızda elde edilen bulgular da öğretmen adaylarının akademik yazma eğitiminin önem ve gerekliliğini kavrayabildiklerini ancak yazılı anlatımda kendilerini yetersiz

\footnotetext{
Adres $\mid$ Address

İstanbul Medeniyet Üniversitesi, Eğitim Bilimleri Fakültesi, Türkçe İstanbul Medeniyet University, Faculty of Education Sciences, ve Sosyal Bilimler Eğitimi Bölümü, Türkçe Eğitimi ABD Cevizli Turkish and Social Scinces Education, Turkish Language Teaching Kampüsü, Kartal-İstanbul/TÜRKIYE $\quad$ Education, Cevizli Campus, Kartal-İstanbul /TURKEY e-posta: editor@rumelide.com 1 e-mail: editor@rumelide.com
} 
hissettikleri, yazmada zorlandıkları yönündedir ve Bağcı'nın çalışmasıyla örtüşmektedir. Akademik yazma, yüksek düzeyde dil bilinci kazanmış bireylerin bilgi ve deneyimlerini zihinsel süreçlerle organize etmeleri için gerçekleştirilecek bir etkinliktir. Yazılı anlatımda yapısal ve anlamsal sorunları olanların akademik yazmada başarılı olmaları zordur (Aydın, 2015).

Literatürde Türkçe akademik yazma eğitimiyle ilgili çalışmaların çoğunda lisansüstü öğrenciler ile öğretim elemanları çalışma grubu olarak seçilmiştir. Bunlardan biri, Tok ve Gönülal (2016), üniversitedeki öğretim elemanlarının akademik yazma sürecinde karşılaştıkları zorlukları ve akademik yazmaya ilişkin ihtiyaçlarını ortaya koymak amacıyla yaptıkları çalışmada, akademik yazma alanında araştırma sürecinin başında olan bireylerin zorlandıklarını dolayısıyla akademik yazma dersine ihtiyaç duyduklarını belirtmiştir. Eğitim programlarında lisansüstü öğrenim gören katılımcılara odaklanan çoğu çalışmada da katılımcıların bilimsel rapor ve akademik yazmada zorlandıkları tespit edilmiştir (Aslan, 2010; Can ve Ceyhan, 2015; Kan ve Gedik, 2016). Aydın ve Baysan (2018), lisansüstü öğrencilerin akademik yazma becerilerine yönelik algılarını metaforlar aracılığıyla belirlemeyi amaçladıkları çalışmada, öğretmen adaylarının yazı ile ilgili metaforları çeşitlilik göstermektedir. Metaforik algıları "uzun / zorlu / zor bir süreç", "yeni şeyler üretme / keşfetme süreci", "kompozisyon / analiz-sentez / yorumlama becerisi gerektiren bir eylem", "uzman desteği gerektiren bir eylem", " çok parçacıklı eylem "," bir eylem dilde ve anlatımda özen gerektirir "," hoş olmayan bir eylem ", neşe veren bir eylem" gibi kategoriler altında değerlendirilmiştir. Araştırmada, lisansüstü öğrencilerin esas olarak akademik yazmanın güçlüğü, uzun zaman alma, yaratma / üretim endişeleri, çok fazla kural ve hoş olmayan faaliyetlere odaklandığı konusunda bulgular elde edinilmiştir. Bu araştırmada da katılımcıların akademik yazma becerisi kazanma noktasında zorluklar yaşadıkları, kendilerini yetersiz buldukları şeklinde bulgulara ulaştığı için lisansüstü çalışmaların sonuçlarıyla örtüşmektedir.

Öğretmen adaylarının Türk Dili II dersinin özü olan akademik yazma eğitiminden olumlu derecede yararlandıkları, \%94,87'sinin araştırma raporunun yazımı, akademik yazı türleri, bilimsel araştırma süreci, etik ilkeler, anlatım biçimleri, tartışmacı metin yazma, özetleme ve başlık oluşturma gibi pek çok konuda bilgi sahibi oldukları anlaşılmıştır. Ancak öğrenilenlerin çoğunun teorik düzeyde olduğu, tartışmacı metin yazma, özet çıkarma, başlık oluşturma kategorilerinde katılımcıların sadece \%7,68'inin kazanım sağladığını belirtmesi, dersin yazma becerisi kazandırma noktasında hedefine ulaşamadığını düşündürmüştür. Ancak öğretmen adaylarına derste yapılan etkinliklere yönelik görüşleri sorulduğunda \%83,34’ü yazma becerisi kazandırdığı için etkinlikleri önemli ve yeterli bulduğunu ifade etmiş, \%15,38'i etkinlikleri kısmen yeterli, ağır ve yetersiz şeklinde nitelemiştir. Bu yetersizlik akademik yazmanın zor ve karmaşık bir süreç olması, çok emek verme, uzun süre ayırma ve çok sayıda uygulama yapmayı gerektiren doğasıyla alakalı olduğu söylenebilir (Bahar, 2014). Aynı zamanda farklı ilgi ve alanlardan gelen öğrencilerin bir arada bu dersi alması, kaynak eksikliği, sınıfların kalabalık olması ve iş yükünün ağırlığı gibi sebepler etkinliklerin yetersiz bulunmasına yol açtı̆̆ söylenebilir. Bu sorunların giderilmesi ve özellikle Türk Dili II dersinin 40 öğrenciyi aşmayan sınıflarda okutulması etkinliklerin sayısının arttıılması noktasında doğru bir yol olabilir. Ayrıca içeriği yenilenen derslerde kullanılacak kaynakların sayı ve kalite bakımından yeterliliğinin sağlanması da önemlidir.

Dönem başında ve sonunda yapılan tartışmacı metin yazma etkinliğinde, öğretmen adaylarının anlatım bozukluğu yapmadan yazma ve yazım kurallarına uyma durumları gözlemlenmiş ve değerlendirilmiştir. Tablo 9'da görüldüğü gibi öğretmen adaylarının anlatım bozukluğu ve yazım yanlışı yapmadan yazma konusunda ilerleme gösteremedikleri tespit edilmiştir. Öğrencilerin orta öğretim boyunca ve lisans kademesinde dahi güz döneminde Türk Dili I dersinde bu konuların

Adres

İstanbul Medeniyet Üniversitesi, Eğitim Bilimleri Fakültesi, Türkçe ve Sosyal Bilimler Eğitimi Bölümü, Türkce Eğitimi ABD Cevizli Kampüsü, Kartal-İstanbul/TÜRKIYE e-posta: editor@rumelide.com 
gösterilmiş olmasına rağmen Türkçeyi doğru kullanmada zayıf oldukları, yazı diline hâkim olamadıkları, dolayısıyla yazma becerisinin tam olarak gelişmediği ortaya çıkmıştır. Yazma becerisi ile ilgili bazı araştırmalar, üniversite öğrencilerinin Türkçe yazma becerilerinin son derece zayıf olduğunu kelime hazinesi, cümle kurma, yazım kuralları vb. bakımından yetersiz olduklarını ortaya çıkarmıştır (Arıcı, 2008; Bağcı, 2007; Doğan, 2002; Kan ve Tiryaki, 2015). Bu çalışmada da benzer olarak öğretmen adaylarının yazım kuralları ve anlatım bozukluğu konularında eksikleri olduğu, bunların yazılı anlatım becerilerini etkilediği ortaya çıkmıştır.

Tartışmacı metin yazma, akademik yazma becerisinin uygulamaya döküldüğü önemli bir etkinlik olduğu için araştırmamızda bu etkinlik üzerinde ayrıca durulmuştur. İlk yazı sonrasında tartışmacı metin oluşturmanın kaideleri ayrıntılı olarak anlatılmış, dönemin sonunda öğrendikleri bilgileri kullanarak etkinlik yeniden tekrarlanmıştır. Öğrencilerin düşünceyi geliştirme yollarından örneklendirmeyi tercih ettikleri, karşılaştırmada zayıf oldukları, tanımlama, alıntı yapma gibi akademik yazmanın önemli unsurlarını kullanmadıkları anlaşılmıştır. Bu etkinlikte öğretmen adaylarının tartışmacı metnin iddia ve karşı iddia gibi temel unsurlarını inşa etmede sorunlar yaşadıklarını, yazılarda kanıtlayıcılık düzeyinin oldukça zayıf olduğu gözlemlenmiştir. Üniversite öğrencilerinin tartışmacı metin yazma becerilerini değerlendiren Coşkun ve Tiryaki (2013) öğrencilerin tartışmacı metin yazarken iddialarını kanıtlama noktasında güçlük çektikleri sonucuna ulaşmıştır. Çalışmamız yazılan tartışmacı metinlerde iddianın gerekçeler göstererek kanıtlanması noktasında öğrencilerin yetersiz olduklarını, tartışmacı yazılarda kanıtlayıcılık düzeyinin zayıf olduğunu ortaya çıkardığı için Coşkun ve Tiryaki’nin çalışması ile örtüşmektedir.

Özbay'a (2010) göre doğru ve iyi yazmak kabiliyete bağlı değildir. Yazma tekniklerini, dil kurallarını, kelime, cümle ve paragraf bilgisini edinip sürekli deneyerek zamanla başarıya ulaşılabilir. Ayrıca, öğrencilerin okuma alışkanlığı kazanması da yazma becerisinin gelişmesini sağlar. Koçak’a (2005) göre çok kitap okuyan öğrencilerin yazılı anlatımları, az kitap okuyan öğrencilerin yazılı anlatımlarına göre daha başarılıdır. Özdemir'e (2011) göre öğrencilerin okuma ve yazma becerileri arasında güçlü bir bağ vardır; bir ay içerisinde hiç kitap okumayan öğrencilerin yazım kurallarına ve noktalama işaretlerine uyma alışkanlığı bir ay içerisinde üç ve üçten fazla kitap okuyanlara göre daha azdır. Göçer (2013) de yazma becerisinin gelişiminde okumanın kayda değer bir etkisi olduğunu tespit etmiştir. Bu sebeple akademik yazma becerisinin gelişmesi öğrencilerin okuma ve araştırma alışkanlıklarının geliştirilmesiyle mümkün olabilir. Nitelikli kitapların seçimi ve okunmasıyla sözcük dağarcığını güçlendirme, bilgi ve kültür birikimi sağlama, düşünme becerisi kazandırma, Türkçenin gramer ve yazma kurallarını öğrenme gibi noktalarda başarı sağlanabilir. Dolayısıyla lisans öğrencilerinin okuma alışkanlığını güçlendirecek aynı zamanda araştırmaya sevk edecek bir sürecin takip edilmesi akademik yazma becerisini güçlendirebilir. Tok'a (2012) göre diğer yazma alanlarında olduğu gibi akademik yazma becerilerinin geliştirilme çabasının da bazı nedenleri vardır. Yazdıklarımızı değerlendiren öğretmenler ya da genel olarak okuyucu kitlesi bizim ifade etmek istediğimizi bütünüyle anlamak ihtiyacı duyarlar. Bu nedenle akademik yazma becerilerinin üniversitesi öğrencilerine kazandırılması gerekmektedir.

Arneback, Englund ve Solbrekke (2017), öğretmen eğitiminde öğretmen adaylarının akademik yazma deneyimlerini değerlendirdikleri çalışmada, öğrencilerin çoğunun üniversitedeki ilk dönemlerinde akademik yazma ve okumanın onlar için yeni olmasından kaynaklı zorlu bir süreç olarak tanımladıkları belirtilmiştir. Bu bakış açısıyla, öğretmen yetiştirme programlarının nasıl düzenlendiği üzerinde düşünmek önemlidir, çünkü öğretmen adaylarının farklı disiplinlerle karşılaşma sırası, bu disiplinlerdeki yazma süreci deneyimlerini etkiliyor gibi görünmektedir. Sonuç olarak Türk Dili II

Adres

İstanbul Medeniyet Üniversitesi, Eğitim Bilimleri Fakültesi, Türkçe ve Sosyal Bilimler Eğitimi Bölümü, Türkçe Eğitimi ABD Cevizli Kampüsü, Kartal-İstanbul/TÜRKIYY e-posta: editor@rumelide.com 
dersinin içeriğinden anlaşıldığı üzere YÖK, daha birinci sınıfta öğretmen adaylarının akademik yazma konusunda bilgi ve beceri kazanmasını sağlayacak bir eğitim almasını hedeflemektedir. Akademik yazma lisansüstü öğrencilerinin ve öğretim görevlilerinin dahi zorlandığı bir konu olduğuna göre, YÖK’ün akademik yazma eğitimini lisans öğrencilerinin almakla yükümlü olduğu bir dersin ana konusu haline getirmesi oldukça doğru bir karar olarak görülmektedir.

Çalışmamızda öğretmen adaylarının Türk Dili II dersinin ana konusu olan akademik yazma konusunu önemli buldukları, bu dersten teorik ve pratik düzeyde bilgi ve beceri kazandıkları anlaşılmıştır. Dersin öğretmen adaylarının akademik yazmaya yönelik yeterliliklerini sağladığı düşünülmektedir. Yazma becerisi zamanla kazanılan bir beceri olduğuna göre, eksikler ve yetersizlikler çaba, odaklanma, alan ve dil hâkimiyeti, kendine güvenme, okuma ve araştırma merakı sayesinde giderilebilir. Akademik yazma ile ilgili bu derste kazanılan bilgi ve becerinin sürdürülmesi, öğrencinin yazı dili edinmesi ve yazma becerisini geliştirmesine katkıda bulunacak bir eğitim-öğretim sürecinin tesis edilmesiyle sağlanabilir. Öğretmen adaylarının lisans boyunca diğer derslerde ödev ve projelere yönlendirilmesi, başarı seviyesinin yazma faaliyetleri üzerinden ölçülmesi sayesinde akademik yazma konusunda yetkinlik kazanmak mümkündür.

\section{Kaynakça}

Akgün, L. (2012). Bilimsel araştırma yöntemleri dersine ilişkin öğretmen adaylarının algı ve beklentileri. Balkesir Üniversitesi Sosyal Bilimler Enstitüsü Dergisi, 15 (27), 21-30.

Alabaş R. (2016). Türk eğitim tarihi dersinin önemi hakkında öğretmen adaylarının görüşleri. Cumhuriyet Uluslararası Eğitim Dergisi, 5 (4), 89-102.

Arıcı, A. F. (2008). Üniversite öğrencilerinin yazılı anlatım hataları. Uludă̆ Üniversitesi Eğitim Fakültesi Dergisi, 21 (2), 209-220.

Arneback, E., Englund, T. ve Solbrekke, T. D. (2017). Student teachers' experiences of academic writing in teacher education- on moving between different disciplines. Education Inquiry, 8 (4), 268-283.

Aslan, C. (2010). Türkçe eğitimi programlarında lisansüstü öğrenim gören öğrencilerin akademik özyeterliklerine ilişkin görüssleri. Mehmet Akif Ersoy Üniversitesi Ĕ̆itim Fakültesi Dergisi, (19), 87-115.

Aydın, G. (2015). Türk dili ve edebiyatı hizmet öncesi öğretmen eğitiminde yansıtıcı öğretim uygulamaların akademik yazma becerilerine etkisi. Erzurum: Atatürk Üniversitesi Eğitim Bilimleri Enstitüsü. Doktora Tezi.

Aydın, G. ve Baysan, S. (2018). Perceptions of postgraduate students on academic writing skills: A metaphor analysis study. Journal of Language and Linguistic Studies, 14(2), 212-239.

Bahar, M. A. (2014). Lisansüstü eğitimde akademik yazma ve önemi. International Journal of Language Academy, 2 (4), 209-233.

Bağcı, H. (2007). Türkçe öğretmeni adaylarının yazılı anlatıma ve yazılı anlatım derslerine yönelik tutumlarının değerlendirilmesi. TÜBAR, (21), 29-61.

Bayat, (N. (2014). Öğretmen adaylarının eleştirel düşünme düzeyleri ile akademik yazma başarıları arasındaki ilişki. Eğitim ve Bilim, 39 (173), 155-168.

Bilgin, N. (2014). Sosyal bilimlerde içerik analizi. Ankara: Siyasal Yayın.

Büyüköztürk, Ş., Kılıç Çakmak, E. Karadeniz, Ş. ve Demirel, F. (2008). Bilimsel araştırma yöntemleri. Ankara: Pegem A Yayıncılı.

Bowker, N (2007). Academic writing: A guide to tertiary level writing. Palmerston North-New Zealand: Massey University. http://owll.massey.ac.nz/pdf/Academic-Writing-Guide.pdf

\footnotetext{
Adres $\mid$ Address

İstanbul Medeniyet Üniversitesi, Eğitim Bilimleri Fakültesi, Türkçe İstanbul Medeniyet University, Faculty of Education Sciences, ve Sosyal Bilimler Eğitimi Bölümü, Türkce Eğitimi ABD Cevizli Turkish and Social Scinces Education, Turkish Language Teaching Kampüsü, Kartal-İstanbul/TÜRKIYY $\quad$ Education, Cevizli Campus, Kartal-İstanbul /TURKEY e-posta: editor@rumelide.com 1 e-mail: editor@rumelide.com
} 
Can, Ş. ve Ceyhan, B. (2015). Eğitim bilimleri enstitüsü lisansüstü öğrencilerinin bilimsel rapor yazma ve yayınlama konusundaki görüşleri (Muğla ili örneği). Sosyal ve Beşeri Bilimler Araştırmaları Dergisi, (35), 42-51.

Chamot, A. U. ve O'Malley, J. M. (1994). The CALLA handbook: Implementing the cognitive academic language learning approach. White Plains, MA: Addison Wesley Longman.

Coffin, C., Curry, M. J., Goodman, S., Hewings, A., Lillis, T. M., Swann, J. (2005). Teaching academic writing. London and New York: Routledge.

Coşkun, E. (2011). Yazma eğitiminde aşamalı gelişim. M. Özbay (Ed.), Yazma Eğitimi (ss. 45-83). Ankara: Pegem Akademi.

Coşkun, E. ve Tiryaki, E. N. (2013). Üniversite öğrencilerinin tartışmacı metin yazma becerileri. Hacettepe Üniversitesi Eğitim Fakültesi Dergisi, 28 (2), 102-115.

Davey, L. (1991). The application of case study evaluations. Practical Assessment, Research \& Evaluation, 2 (9). Erişim adresi:

http://PAREonline.net/getvn.asp?v=2\&n=9

Doğan, Y. (2002). Türkçe öğretmenliği birinci sınıfta okuyan öğrencilerin okuma ve yazma becerileri ile genel kültür düzeyleri üzerine bir araştırma. Ankara: Gazi Üniversitesi Eğitim Bilimleri Enstitüsü. Yüksek Lisans Tezi.

Ekmekçi, A. ve Konaç, E. (2009). Bilimsel yazımın bazı temel kuralları. TUBAV Bilim Dergisi, 2 (1), 117-121.

Gillett, A., Hammond, A., Martala, M. (2009). Successful academic writing, Essex: Pearson Longman.

Göçer, A. (2013). Türkçe öğretmeni adaylarına göre yazma becerisinin ediniminde ve gelişiminde etkili olan unsurlar. Mustafa Kemal Üniversitesi Sosyal Bilimler Enstitüsü Dergisi, 10 (24), 1-14.

Hartley, J. (2008). Academic writing and publishing. London and Newyork: Routledge.

Kan, M. O. ve Gedik, F. N. (2016). Türkçe eğitimi alanında yüksek lisans tezi tamamlayanların akademik yazma ve tez oluşturma sürecine ilişkin görüşleri. Yükseköğretim ve Bilim Dergisi, 6 (3), 402-408.

Kan, M. O. ve Tiryaki, E. N. (2015). Türkçe öğretmeni adaylarının metin oluşturmadaki sorunları. Mersin Üniversitesi Ĕ̆itim Fakültesi Dergisi, 11 (2), 550-562.

Karasar, (2012). Bilimsel araştırma yöntemleri. Ankara: Nobel Yayın.

Koçak, A. (2005). Bolu ili ilköğretim beşinci ve sekizinci sınıf öğrencilerinin yazılı anlatım becerileri üzerine bir araştırma. Bolu: Abant İzzet Baysal Üniversitesi Sosyal Bilimler Enstitüsü. Yüksek Lisans Tezi.

Miles, M.B. ve Huberman, A. M. (1994). Qualitative data analysis: an expanded sourcebook. London: Sage Publication.

Monippally, M. M. ve Pawar, B. S. (2010). Academic writing - A guide for management students and researchers. New Delhi: Vivek Mehra for Response Books.

Sarıkaya, B. (2020). Akademik dil ve yazının önemi. M. N. Kardaş, R. Koç (Ed.), Türk Dili 2 Akademik Yazma Ĕ̆itimi (ss. 1-16), Ankara: Pegem Akademi.

Özbay, M. (2010). Türkçe öğretimi yazıları. Ankara: Öncü Kitap.

Özdemir, N. H. (2011). Türkçe öğretmen adaylarının yazma alş̧kanlıklar üzerine bir araştırma. Malatya: İnönü Üniversitesi Eğitim Bilimleri Enstitüsü. Yüksek Lisans Tezi.

Tok, M. (2012). Türkçe’nin yabancı dil olarak öğretiminde akademik yazma becerilerinin geliştirilmesine yönelik uygulamal bir çalışma (Doktora Tezi). Çanakkale Onsekiz Mart Üniversitesi, Çanakkale.

Tok, M. (2013). Türkçenin yabancı dil olarak öğretiminde akademik yazma ihtiyacı. Mustafa Kemal Üniversitesi Sosyal Bilimler Enstitüsü Dergisi, 10 (23), 1-25. 
Tok, M. ve Gönülal, N. (2016). Akademik yazma sürecine ilişkin bir ihtiyaç analizi. International Journal of Turkish Education and Training, 1 (1), 143-161.

Tompkins, G. E. (2009). Language Arts. New Jersey: Pearson.

Wang, Y. (2012). Differences in l1 and l2 academic writing. Theory and Practice in Language Studies, 2 (3), 637-641.

Whitaker, A. (2009). Academic writing guide. Bratislava-Slovakia: City University of Seattle. Erişim adresi: http://www.vsm.sk/Curriculum/academicsupport/academicwritingguide.pdf

Yıldırım, A. ve Şimşek, H. (2013). Sosyal bilimlerde nitel araştırma yöntemleri. Ankara: Seçkin Yayıncilı.

Yin, R. K. (2003). Case study research: Design and methods. Thousand Oaks: Sage Publications.

Yükseköğretim Kurulu Başkanlığı (YÖK) (2017a). Öğretmen yetiştirme lisans programları. Ankara. Erişim adresi:

https://www.yok.gov.tr/Documents/Kurumsal/egitim_ogretim_dairesi/Yeni-Ogretmen-YetistirmeLisans-Programlari/AA_Sunus_\%20Onsoz_Uygulama_Yonergesi.pdf

YÖK (2017b). Okul öncesi öğretmenliği lisans programı. Ankara. Erişim adresi:

https://www.yok.gov.tr/Documents/Kurumsal/egitim_ogretim_dairesi/Yeni-Ogretmen-YetistirmeLisansProgramlari/Okul_Oncesi_Ogretmenligi_Lisans_Programi.pdf

\section{Extended Summary}

\section{Introduction}

The ability of an individual to express themselves through writing, namely writing skill, is the most difficult skill among the language skills, when compared with other language skills such as speaking, listening, and reading. The development of a person's writing skills is tied to other language skills, e.g., vocabulary, language sensitivity, observation and regular writing. Academic writing is an important element in many university courses. Although academic writing assignments may have different names, such as, essays, term papers, discussion papers, analysis papers, research papers and informative papers, the same goals and principles are targeted. In the context of these definitions, the aim of academic writing in universities is twofold: to provide the student (i) the ability to express academic thought in writing; and (ii) the skills necessary to able to convert scientific knowledge and findings, i.e., scientific research, into writing. Therefore, academic writing is basically a process in which scientific research is turned into a report, and this process must be carried out on the basis of certain rules. A literature review conducted on the subject matter has revealed the following rules; strictly complying with the rules of academic language and academic expression; writing using subjectspecific terms and concepts; expressing thoughts as clearly as possible; maintaining an objective perspective; paying attention to the characteristics and structure of the type of writing; writing on the basis of planned narration, in an explanatory manner, with an approach persuading the reader, along with citing the information obtained in the previous studies; and including sections, such as "introduction", "discussion", "conclusion and recommendations", in the academic writing.

The Council of Higher Education has made important changes to the curricula that have been implemented in all departments of the Faculty of Education. In this framework, the curriculum of the Turkish Language-II course, which is taught in the freshman year, has been refined to develop academic language/vocabulary and academic reading and writing, as of the 2018-2019 academic year. The main aim of this study is to determine the opinions of prospective Turkish-language

\footnotetext{
Adres $\mid$ Address

İstanbul Medeniyet Üniversitesi, Eğitim Bilimleri Fakültesi, Türkçe İstanbul Medeniyet University, Faculty of Education Sciences, ve Sosyal Bilimler Eğitimi Bölümü, Türkce Eğitimi ABD Cevizli Turkish and Social Scinces Education, Turkish Language Teaching Kampüsü, Kartal-İstanbul/TÜRKIYE $\quad$ Education, Cevizli Campus, Kartal-İstanbul /TURKEY e-posta: editor@rumelide.com 1 e-mail: editor@rumelide.com
} 
teachers/instructors on academic-writing education. This study is thought to be important for the field as it will provide feedback regarding the (i) implementation of the new curriculum; and (ii) students' problems, deficiencies and needs.

\section{Method}

The study was carried out within the scope of the "case study" design, which is one of the qualitative research designs. The study group comprised 110 undergraduate freshman students enrolled at the Fazıl Küçük, Faculty of Education, European University of Lefke, Turkish Republic of Northern Cyprus, during the 2018-2019 Academic Year. The study group was formed on the basis of typical case sampling, which is one of the purposeful sampling methods. A semi-structured interview form, prepared specifically for academic writing and based on expert opinion, was used as the datacollection tool. The data obtained as a result of the study were analyzed via content analysis, and numerical and proportional classification was performed by way of frequency analysis.

\section{Result and discussion}

Our findings from this study revealed that $79.49 \%$ of prospective teachers did not understand the concept of academic writing at the preliminary interview stage; however, this ratio reduced to $6.41 \%$ at the time of the final interview, indicating that they had developed a conceptual understanding of academic writing.

Participants had defined academic writing in various ways, e.g., "putting the scientific research process on paper", "writing in a scientific style", "objective and verifiable writing", and "scientific writing". Most of the participants had stated that they did not understand academic writing prior to this study; some students even confusing academic writing with official correspondence. In this context, it can be said that the Turkish Language-II course contributed to the students' understanding of academic writing.

In the final interview, $97.44 \%$ of the participants compared to $70.51 \%$ of preliminary-interview participants, stated that they find academic writing important. This was with the thought that it will contribute to their educational and professional lives and that it will benefit them during their postgraduate education. Students were also found to have exhibited a positive attitude towards the academic writing course. This result indicates that these prospective teachers came to understand the importance and necessity of academic writing education. The participants stated that they find themselves inadequate with the thought that they do not possess the necessary knowledge or experience in academic writing. It has been reported in other studies that most of the students receiving postgraduate education in the Education field have difficulties in reporting scientific content and academic writing. As academic writing is a subject that even graduate students and lecturers have difficulties with, it can be said that the Council of Higher Education has made the correct decision to incorporate academic-writing education in the curriculum of Turkish Language-II course, a compulsory course for undergraduate students. The Turkish Language-II course is thought to be sufficient in preparing university students for academic writing. However writing activities should not only be limited to this course, and an education and training process that will contribute to the student's acquisition of literary language and writing skills should be established throughout the undergraduate program. In addition, gaining a habit for reading also improves one's writing skills.

\footnotetext{
Adres $\mid$ Address

İstanbul Medeniyet Üniversitesi, Eğitim Bilimleri Fakültesi, Türkçe İstanbul Medeniyet University, Faculty of Education Sciences, ve Sosyal Bilimler Eğitimi Bölümü, Türkce Eğitimi ABD Cevizli Turkish and Social Scinces Education, Turkish Language Teaching Kampüsü, Kartal-İstanbul/TÜRKIYE $\quad$ Education, Cevizli Campus, Kartal-İstanbul /TURKEY e-posta: editor@rumelide.com 1 e-mail: editor@rumelide.com
} 
Consequently, strengthening their reading habit also improves critical thinking levels of prospective teachers.

A number of studies related to writing skills revealed that university students have extremely poor Turkish writing skills, be it vocabulary, building sentences, spelling rules, etc. The results of our study reflect the findings of those works, since we have also found that students possess poor writing skills in activities related to academic writing.

Argumentative text writing is an important activity where academic writing skills are put into practice. It was determined, as a result of the said activity carried out within the scope of this study, that prospective teachers had problems building the basic elements of argumentative text, such as claim and counter-claim; and that the substantiation level of their writings was quite weak. Additionally, it was observed that they preferred exemplification from among the methods of developing thought, that they were weak in drawing comparisons, and that they did not use certain important elements of academic writing, such as making definitions and quotations.

The majority of the participants acquired sufficient theoretical knowledge about academic writing, which is the main subject of the Turkish Language-II course. This theoretical knowledge is expected to contribute to the student's writing skills, especially when put into practice in other courses. For this purpose, writing assignments/projects should also be used to assess the students' success in addition to exams. 